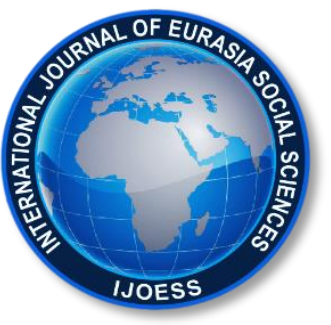

International Journal of Eurasia Social Sciences

Vol: 11, Issue: 39, pp. (XX-XX).

Article Type: Research Article

Received: 14.03.2019 Accepted: 18.03.2020

\title{
A QUALITATIVE VIEW TO CHILDREN'S PROBLEM SOLVING SKILLS
}

\author{
Elifcan CESUR \\ Res. Asst.., Kırklareli University, Turkey, elifcancesur@gmail.com \\ ORCID: 0000-0002-9364-2293 \\ Kevser TOZDUMAN YARALI \\ Asts. Prof., Kırklareli University, Turkey, kevseryarali@klu.edu.tr \\ ORCID: 0000-0002-7765-0461
}

\begin{abstract}
Problem solving is one of the important skills, which enables individuals to adapt to life and is associated with skills like theory of mind, empathy and self-regulation, in their life. Problem solving is an improvable skill and should be supported as from early childhood years. The purpose of this study is to determine how children generate solutions to problems and how they feel in such cases. As long as children are good problem solvers, they will find effective solutions to all kinds of problems. In the study, the qualitative model and the case design were used. The data of study were obtained from the children attending a kindergarten in the city center of Kırklareli in the school year of 2016-2017. Eleven children who were selected on a volunteer basis were included in the study where content analysis was carried out. Among the children who participated in the study, six were girls and five were boys. During the application, a puppet and five problem statuses were used. The data collected as a result of one-to-one applications with the children were examined with content analysis method. As a result of the study, it was observed that the children were able to generate effective solutions including the use of empathy and self-regulation skills to the problem statuses; however, they had difficulty in naming their emotions in relation to problem statuses. The results of the study suggest that primarily parents and educators should emphasize emotions more and encourage children to think about their emotions. Additionally, qualitative studies with larger sample groups concerning theory of mind, problem solving, empathy and self-regulation skills can help to understand the development process of these skills better.
\end{abstract}

Keywords: Problem solving skill, qualitative model, emotions. 


\section{INTRODUCTION}

Problem solving is one of the important skills in an individual's life. Heppner and Krauskopf (1987) state that problem solving is a series of cognitive and affective processes and behavioral reactions that are necessary for a person to adapt to requirements and difficulties. On the other hand, D'Zurilla et al., (2004) define problem solving as a cognitive-behavioral process where interventions are made for generating effective solutions to everyday problems and which is formed by the individual. Being an improvable skill, problem solving skill enables the individual to adapt to the environment ( $D^{\prime} z u r i l l a$ et al., 2004). Thus, it is of prime importance for children to have problem solving skills as from the preschool period so that they will adapt to the real life. As long as children are good problem solvers, they will find effective solutions to all kinds of problems.

There are many factors affecting the problem solving process. Self-regulation and empathy ability which are related with theory of mind can be given as an example for these factors. Individuals with the skill of theory of mind, which is defined as a skill of understanding people's desires, intentions and emotions, and making explanations and interpretations in the interaction with people according to these mental statuses (Astington \& Baird, 2005) recognize that other people have a different mental structure, knowledge and experience. Signs of theory of mind appear averagely at age one (Onishi \& Baillergeon, 2005; Sodian, 2011), make an important progress at age four (Astington \& Gopnik, 1991; Wellman, 1990; Wellman \& Lagattuta, 2000) and become same as adults around at age five (Carlson \& Moses, 2001). This development shows a parallelism with the development encountered in self-regulation skills (Kochanska, Coy, \& Murray, 2001). According to Zimmerman (2000); self-regulation signifies an individual's control of learning process cognitively, motivationally and behaviorally and is also defined as an ability of delaying or suppressing behaviors, tendencies and desires, controlling and regulating emotions and giving effective and appropriate answers/reactions to both internal and external demands (Bauer \& Baumeister, 2011; Koole, Van-Dillen \& Sheppes, 2011; Raffaelli, Crockett \& Shen 2005). Researchers state that self-regulation supports the skill of understanding other people's minds (Riggs et al., 2006) and consequently can affect social behaviours (Bierman et al., 2008; Fabes \& Eisenberg, 1992; Montroy et al., 2014). It is known that children who do not have the developed self-regulation skill also experience peer rejection (McCelland \& Tominey, 2011; Montroy et al., 2014) and academic difficulties (Bondurant, 2010; Nota et al., 2004; Smith-Donald et al., 2007).

An individual's concern about solving a problem depends on the congruence between personality traits and problem characteristics (Eskin, 2009). The individual can understand emotions, thoughts and behaviors of other people, put himself in their place and accept them as they are and respect their behaviors with the help of the ability of developing empathy, which can be regarded under the personality structure (Köksal Akyol \& Didin, 2016). According to Strayer and Robert (2004), empathic children who understand emotions and viewpoints of other people better are more successful in solving social problems and decreasing anger and conflicts.

Being able to interpret warnings from other people emotionally requires being aware of emotions and understanding emotions accurately. Unless emotions are understood accurately, children will have a confusion 
and a difficulty in giving right reactions in the right place (Greenspan, Wider and Simon, 2016). Difficulties experienced in the processes of being aware of and understanding emotions may also affect self-regulation skills of children negatively and thus, destroy their social behaviors (Riggs, et al., 2006). When children are unable to express their emotions, they also have a higher tendency to violence. It is indicated that many children and teenagers with a tendency to violence are unable to describe their emotions and predict the results of their behaviors (Greenspan \& Salmon, 2013). Children who are able to name clearly and accurately their emotions about the conditions will be more sufficient about what to do to cope with these emotions. For example, a child who feels unhappy may take action to change the condition, reduce his sadness and change his emotion when he is able to name that emotion accurately and know the reason of his sadness. This procedure is called as emotional regulation (Southam-Gerow, 2014) and is included in the concept of selfregulation (McClelland \& Tominey, 2014).

According to social learning theory, individuals shape their behavioral styles, ways of expressing their emotions and thoughts and communication structures in their social-cultural environment (Senemoğlu, 2007). If school and family members which constitute the social-cultural environment do not support the skills of children to express their emotions and thoughts, do not talk about their emotions, direct them to suppress their emotions; they may cause children to have a difficulty in realizing and expressing their emotions. The studies have emphasized that experiences and learnings which occur in developmental processes as from childhood are effective in emotional regulation including expression, recognition, and control of emotions by individuals (Koçak, 2002). When examining the relevant literature; there are studies indicating that there is a correlation between emotional self-regulation and externalized behavioral problems in preschool children (Hill et al., 2016), children who are able to understand, recognize and express the emotions of their peers better display more positive social behaviors (Downs-Strand, 2008; Fabes et al., 1999; Garner-Waajid, 2012) and children who have a difficulty in expressing their emotions will develop anxiety and depression.

No matter how old they are, individuals face many problems to be solved in their daily lives. As these problems affect their social adaptation, it is highly important to support problem solving skill, which is a learnable and improvable skill, as from early ages. The ways followed and the things given importance in solving problems will determine the effectiveness of solutions. While trying to solve a problem; acting flexibly, controlling and regulating emotions, giving effective and appropriate answers/reactions to demands and viewing an event from the perspective of another person are very important skills in order to overcome the problem. All these skills that are considered necessary to solve problems efficiently are directly related with self-regulation and empathy skills within the frame of theory of mind. The related studies focus upon how children are successful in problem solving skills (for example, Dereli-Iman, 2013; Yılmaz \& Tepeli, 2013), whereas this study laid emphasis on solutions generated by children in this process. From this point of view, answers are sought to the following questions in the study:

1. How do children express their emotions in relation to problem statuses? 
2. How do children generate solutions to problem statuses?

3. How do the solutions that children produce for problem situations differ by gender?

\section{METHOD}

\section{Study Model}

The study was designed in the qualitative model using the case design for the purpose of revealing examples to solutions generated by five-year-old children in relation to problem statuses for both readers and other researchers and contributing to the development of understandings and experiences concerning theory of mind, empathy and self-regulation skills. Case study requires examining a limited system profoundly. It associates a current phenomenon with the connection in real life (Merriam, 2015). What is examined here is children's problem solving skills. Following stages are followed in a case study: Processes of developing the study questions, developing the sub-problems of the study, determining an analysis unit, determining the case to be studied, selecting the participants, collecting data and associating the data with sub problems, analyzing and interpreting the data and reporting the case study (Yıldırım \& Şimşek, 2016). The process in this study is as follows:

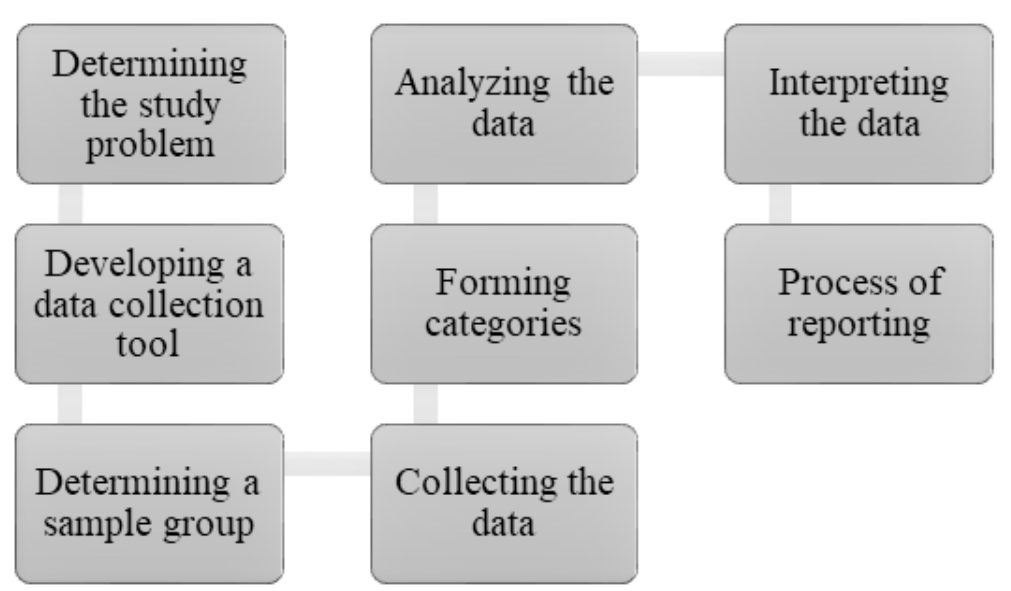

Figure 1. Flow Plan Showing the Data Analysis Process

\section{Sample Group}

The data of study were obtained from the children attending a kindergarten in the city center of Kırklareli in the school year of 2016-2017. Being among non-random sampling methods, convenience sampling method was used for the sample group of the study. The sample group of the study consisted of 11 five-year-old children. Among the children who participated in the study, six were girls and five were boys. One of the boys stated that he did not want to continue after the first problem status and returned to his class. The data were collected between 01.04.2017 \& 30.04.2017. 


\section{Data Collection}

In the study, the data were collected using the interview technique. Interview is an important data collection tool. It is also an important source for learning a participant's point of view, intention, emotions, and thoughts (Merrriam, 2015). An interview form was developed by the researchers before interviewing the children. Firstly, five different problem statuses were created. A puppet was designed for a child named Çiko, the main hero of problem statuses. The puppet was designed to make the process more enjoyable for the children and enable them to establish an identification more easily. No distinct gender discrimination was performed in order for the designed puppet not to be directional. Additionally, a particular attention was paid to making the puppet straight-faced (Image 1).

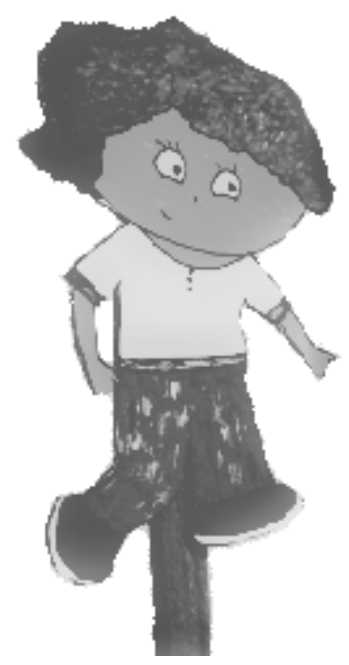

Image 1. The Puppet Used for Problem Statuses

A pilot study was conducted with two children in order to reveal the deficiencies and disputes during the interview. The children included in the pilot study were selected as a girl and a boy. The study was conducted individually with each child and after introducing Çiko, each problem status was read by turns and the answers of the children were recorded by an implementer and another researcher who listened to the child. Çiko was introduced to the children as follows: "This is Çiko. Çiko is five years old and goes to kindergarten. Çiko has some problems just like every child. Now let's have a look at his problems and help him." Corrections were made in question statements after the pilot study and additional questions were asked when necessary so that the children could make explanations. The same questions were asked to the children after each problem status (What might have Çiko felt in that condition?, What can Çiko do in this condition?). When considering the questions asked within the scope of the study, it could be asserted that the interview conducted with the children was a semi-structured interview. In a semi-structured interview, questions are open-ended, but the interview is directed by questions or a subject in order to reveal the subjects to be explored. Open-ended questions pave the way for forming new opinions (Merriam, 2015). In this study, the children were expected to generate different solutions to problem statuses. 


\section{Data Analysis}

The data collected using the interview technique were evaluated with content analysis. Categories were formed according to the children's answers for the content analysis. Categorization is a data analysis and should be started during data collection. Categories should be able to answer study questions (Merrriam, 2015). The categories in this study were formed by evaluating the answers of 11 children to each problem status. Thus, different categories emerged for each problem status.

In order to increase the validity of the study, the children's answers were directly quoted under the table concerning each problem status. Reliability of the data analysis was calculated using Miles and Huberman's formula (2015) [Consensus/ (Consensus + Dissensus) X 100]. Accordingly, the two researchers formed the tables of all problem statuses together and $100 \%$ reliability was provided.

\section{Role of the Researcher}

The children who were interviewed were selected on a volunteer basis. In the classroom, the children were informed about the extent of the study in general terms and that texts including problem statuses would be read during interviews. The children who demanded to participate in the study were taken in an empty classroom respectively and the application was performed. Before the application, a short conversation was made with the child and then the puppet was introduced to her or him. A particular attention was paid to maintaining the application as a game. When any child lost interest, additional questions were asked to return to the subject. One boy who wanted to discontinue the process returned to his class and was not forced for the study. All the children who participated in the study were given codes instead of their names. In addition, the letter $\mathrm{G}$ was used for girls and $\mathrm{B}$ for boys and they were given numbers.

\section{FINDINGS}

The results obtained in the study are presented in tables.

Table 1. Emotions Specified by the Children in Relation to Problem Statuses

\begin{tabular}{|c|c|c|c|c|c|c|c|c|c|c|c|}
\hline & G1 & G2 & G3 & G4 & G5 & G6 & B1 & B2 & B3 & B4 & B5 \\
\hline $1^{1^{\text {st }}}$ Problem Status & $\begin{array}{l}\text { D্ } \\
\text { ల }\end{array}$ & 胥 & ' & 胥 & $\underset{\sqcup}{\mathbb{\Psi}}$ & ' & $\stackrel{\infty}{\frac{L}{<}} \geq_{2}$ & i্ & $\begin{array}{l}\text { D্ } \\
\text { ల }\end{array}$ & ' & $\underset{\sqcup}{\mathbb{\Psi}}$ \\
\hline $\begin{array}{c}2^{\text {nd }} \\
\text { Problem Status }\end{array}$ & $\begin{array}{l}\text { ర్ల } \\
\text { D }\end{array}$ & $\underset{⿱ 亠 䒑 ⿰ 丿 ⿱ 丄 𠃍 ~}{\stackrel{1}{<}}>$ & ర్ల & 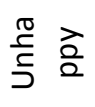 & 胥 & $\stackrel{\bar{\pi}}{n}$ & 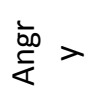 & $\underset{\frac{1}{\alpha}}{\stackrel{\frac{1}{4}}{c}}>$ & 这 & 完 & $\underset{\frac{1}{\alpha}}{\stackrel{\frac{1}{c}}{c}}>$ \\
\hline $\begin{array}{c}3^{\text {rd }} \\
\text { Problem Status }\end{array}$ & ర్ల & 总 & D & $\begin{array}{l}\text { à } \\
\frac{2}{2} \\
\frac{0}{1} \\
\frac{1}{5}\end{array}$ & ర্ & ర্ & 竞 & $\underset{\tilde{n}}{\tilde{n}}$ & $\begin{array}{l}\text { D } \\
\text { ల }\end{array}$ & D & ' \\
\hline
\end{tabular}




\begin{tabular}{|c|c|c|c|c|c|c|c|c|c|c|c|}
\hline $\begin{array}{c}4^{\text {th }} \\
\text { Problem Status }\end{array}$ & $\begin{array}{l}\overrightarrow{\widetilde{D}} \\
\text { D. }\end{array}$ & $\begin{array}{l}\bar{\nabla} \\
\tilde{n}\end{array}$ & 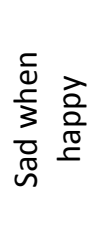 & $\begin{array}{l}\frac{2}{2} \\
\frac{2}{0} \\
\frac{5}{5}\end{array}$ & $\begin{array}{l}\bar{\pi} \\
\tilde{n}\end{array}$ & $\begin{array}{l}\bar{\sigma} \\
\sim \\
\sim\end{array}$ & 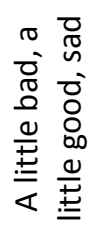 & $\begin{array}{l}\frac{2}{00} \\
\frac{2}{4}\end{array}$ & 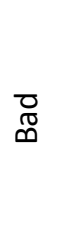 & 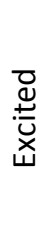 & $\begin{array}{l}\overrightarrow{\widetilde{D}} \\
\infty\end{array}$ \\
\hline $\begin{array}{c}5^{\text {th }} \\
\text { Problem Status }\end{array}$ & $\frac{n}{0}$ & $\begin{array}{l}\bar{\nabla} \\
\tilde{n}\end{array}$ & $\begin{array}{l}\bar{\nabla} \\
\sim\end{array}$ & $\begin{array}{l}\frac{a}{2} \\
\frac{0}{0} \\
\frac{\pi}{5} \\
\frac{1}{5}\end{array}$ & $\begin{array}{l}\bar{\nabla} \\
\tilde{n}\end{array}$ & $\begin{array}{l}\bar{\nabla} \\
\sim \\
\sim\end{array}$ & $\begin{array}{l}\bar{\nabla} \\
\sim\end{array}$ & ' & $\begin{array}{l}\bar{\Xi} \\
\bar{\infty}\end{array}$ & ' & D్ల్ల \\
\hline
\end{tabular}

When examining Table 1, it was observed that the children were able to establish empathy with Çiko and consider events from Çiko's perspective, but they could not name Çiko's emotions accurately in relation to these problem statuses. For example, the emotion of disappointment was tried to be explained by two children with statements, "sad when happy" (G3) and "a little bad, a little good, sad" (B1).

Table 2. Solutions Offered by the Children in Relation to the First Problem Status

\begin{tabular}{cllll}
\hline \multicolumn{5}{l}{ Çiko went shopping with his mother on a holiday. While they were visiting stores together, Çiko } \\
saw a giant teddy bear. He ran into the store and started playing with the teddy bear. When he \\
returned to show his mother the teddy bear, he realized that his mother was not there. What can
\end{tabular}

When examining Table 2, it was remarkable that the boys usually tended to receive support from a professional mostly concerning security in their solutions to the problem status, whereas all the girls, except for one, did not prefer that solution. For example, while B5 stated; "He can go to a police station.", B2; "... He can call the police if he knows the number." as a solution, G1 stated; "He can call for help, go to the cash point and ask about his mother and they may direct him.". Another remarkable point in answers was that some of the boys just ignored the problem status. For example, B3 stated; "He can play with his toys, watch the television and paint. His mother is probably drinking tea in a market." as a solution to that problem status. 
Table 3. Solutions Offered by the Children in Relation to the Second Problem Status

His father bought Çiko his favorite problem status book on his birthday. Çiko read the book and then placed it in a front row on his bookshelf. He looked at his new book at every opportunity and $2^{\text {nd }} \quad$ became happy. One day, when he went into his room to look at his book again, he saw that his
little brother had torn the pages of the book. What can Ciko do in this condition? $\begin{array}{clllll}\text { Problem } & \text { Putus } & \text { Fix it } & \text { Buy a new one } & \text { Put it in another } & \text { Distract new }\end{array}$

\begin{tabular}{lll} 
G1 & $\begin{array}{l}\text { place where his } \\
\text { brother can't } \\
\text { reach }\end{array}$ & $\begin{array}{l}\text { His } \\
\text { brother's } \\
\text { attention }\end{array}$ \\
G2 & & $\begin{array}{l}\text { book from his } \\
\text { brother }\end{array}$ \\
G3 & & \\
G4 & & \\
G5 & & \\
G6 & & \\
B1 & & \\
B2 & & \\
B3 & & \\
B4 & & \\
B5 & & \\
\hline
\end{tabular}

When examining Table 3, it was determined that while the girls offered more constructive/functional solutions like fixing and buying a new one in relation to the problem status, the boys tended to abstain from problem statuses. The boys preferred not to take an active role in solving problems. For example, B1 stated; "He can tell his father that his brother had torn the book. He had probably asked why he had torn it and his brother had probably said that he had done it because he was jealous. He can put the book somewhere higher and give his brother something else to play with." as a solution to that problem. On the other hand, one of the girls (G6) stated; "He can glue, staple and fix it" as a solution. Another girl (G4) stated; "He can glue those pages.".

Table 4. Solutions Offered by the Children in Relation to the Third Problem Status

\begin{tabular}{|c|c|c|c|c|c|c|c|c|}
\hline \multirow[b]{2}{*}{$\begin{array}{l}3^{\text {rd }} \\
\text { Problem } \\
\text { Status }\end{array}$} & \multicolumn{8}{|c|}{$\begin{array}{l}\text { Çiko was invited to a birthday party of one of his best friends. He wanted to wear his green t-shirt } \\
\text { to the party. But his mother refused it. She did not allow Çiko to go to the birthday party with that } \\
\text { t-shirt. What can Çiko do in this condition? }\end{array}$} \\
\hline & Request & $\begin{array}{l}\text { Generate a } \\
\text { solution } \\
\text { according to } \\
\text { his mother's } \\
\text { reason }\end{array}$ & $\begin{array}{l}\text { Wear a long- } \\
\text { sleeved } \\
\text { shirt/wear } \\
\text { something } \\
\text { on the t- } \\
\text { shirt }\end{array}$ & $\begin{array}{l}\text { Give up } \\
\text { going }\end{array}$ & $\begin{array}{l}\text { Wear } \\
\text { in } \\
\text { secret }\end{array}$ & $\begin{array}{l}\text { Wear } \\
\text { another } \\
\text { t-shirt }\end{array}$ & Insist & $\begin{array}{l}\text { Bargain } \\
\text { with the } \\
\text { mother }\end{array}$ \\
\hline G1 & & & & & & & & \\
\hline $\mathrm{G} 2$ & & & & & & & & \\
\hline G3 & & & & & & & & \\
\hline G4 & & & & & & & & \\
\hline G5 & & & & & & & & \\
\hline G6 & & & & & & & & \\
\hline B1 & & & & & & & & \\
\hline B2 & & & & & & & & \\
\hline B3 & & & & & & & & \\
\hline B4 & & & & & & & & \\
\hline B5 & & & & & & & & \\
\hline
\end{tabular}


When examining Table 4, it was observed that while the girls tried to attain their demands in relation to the mentioned problem status by 'requesting', the boys preferred bargaining and insisting. For example, G3 stated; “He can persuade his mother by just saying please. His mother shouldn't make him wear the things he doesn't like.", whereas B1 stated; "He can wear that t-shirt in summer. He had probably asked his mother to wear the t-shirt in summer.". Another important result of the study was that the three children automatically established a cause-effect relationship in relation to the problem status. For example, G4 stated; "He should ask his mother why and learn the reason. If he gets cold, he can wear a sweater or wrap himself in his arms.", whereas G5 stated; "He can wear a coat.".

Table 5. Solutions Offered by the Children in Relation to the Fourth Problem Status

\begin{tabular}{|c|c|c|c|c|c|}
\hline \multirow{2}{*}{$\begin{array}{c}4^{\text {th }} \\
\text { Problem } \\
\text { Status }\end{array}$} & \multicolumn{5}{|c|}{$\begin{array}{l}\text { Çiko made a fun plan with his father for the weekend holiday and was looking forward to that day } \\
\text { But then he learned that his father had to work. What can Çiko do in this condition? }\end{array}$} \\
\hline & $\begin{array}{l}\text { Make a } \\
\text { new plan }\end{array}$ & \multirow[t]{3}{*}{$\begin{array}{l}\text { Insist on the } \\
\text { former plan }\end{array}$} & \multirow[t]{6}{*}{$\begin{array}{l}\text { Go in secret } \\
\text { on his own }\end{array}$} & \multirow[t]{7}{*}{$\begin{array}{l}\text { Wait for } \\
\text { his father }\end{array}$} & \multirow[t]{10}{*}{ Disregard } \\
\hline G1 & & & & & \\
\hline $\mathrm{G} 2$ & & & & & \\
\hline G3 & & & & & \\
\hline G4 & & & & & \\
\hline G5 & & & & & \\
\hline G6 & & & & & \\
\hline B1 & & & & & \\
\hline B2 & & & & & \\
\hline B3 & & & & & \\
\hline B4 & & & & & \\
\hline B5 & & & & & \\
\hline
\end{tabular}

When examining Table 5, it was observed that while the girls sought out a novelty and were able to generate alternative solutions in relation to the problem status, the boys had a difficulty in inclining to new conditions that might solve the problem. For example, G1 stated; “... He can make a plan with his mother. He can allow his father to go to work. Or he can play at home.", G5 stated; "He can go somewhere else without his father. I would go home to do something else. I would draw a nice picture for my mother.", B1 stated; "He must have waited for his father and they must have played together afterwards." And B2 stated; "If he insists, his father can take him there..." as a solution.

Table 6. Solutions Offered by the Children in Relation to the Fifth Problem Status

\begin{tabular}{|c|c|c|c|c|}
\hline \multirow{2}{*}{$\begin{array}{l}5^{\text {th }} \\
\text { Problem } \\
\text { Status }\end{array}$} & \multicolumn{4}{|c|}{$\begin{array}{l}\text { His mother made chocolate ice-cream for Çiko on a summer day. The ice-cream had to be kept in a } \\
\text { deep freeze until the evening so that it would be ready. But Çiko wanted to eat the ice-cream } \\
\text { immediately. What can Çiko do in this condition? }\end{array}$} \\
\hline & $\begin{array}{l}\text { Waste time in an activity (like } \\
\text { playing, drawing, reading, } \\
\text { watching the TV, sleeping) }\end{array}$ & $\begin{array}{l}\text { Make the ice-cream } \\
\text { freeze quickly }\end{array}$ & Wait & $\begin{array}{l}\text { Buy ice-cream } \\
\text { from a market }\end{array}$ \\
\hline \multicolumn{5}{|c|}{ 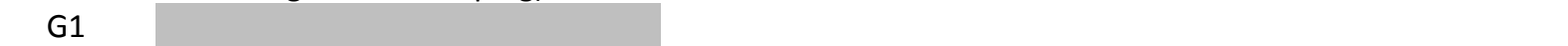 } \\
\hline \multicolumn{5}{|l|}{$\mathrm{G} 2$} \\
\hline \multicolumn{5}{|l|}{ G3 } \\
\hline \multicolumn{5}{|l|}{ G4 } \\
\hline \multicolumn{5}{|l|}{ G5 } \\
\hline G6 & & & & \\
\hline
\end{tabular}


When examining Table 6; it was observed that the children could generally command themselves in situations where they had to wait, just like in the problem status, delay the pleasure and did not insist. For example, G1 stated; "He can sleep, play games and watch the television with his mother.", B1 stated; "He had probably waited patiently until the evening without eating the ice-cream." and B5 stated; "He can do something that would make him forget the ice-cream. Then, he can remember it in the evening. He can play games, go to work with his father, and spend time like that.".

\section{CONCLUSION and DISCUSSION}

This study investigated how preschool children expressed their emotions in relation to problem statuses, how they generated solutions to problems and whether these solutions differentiated according to gender or not. The results in the study are briefly presented as follows.

As a result of the study, it was seen that the children were able to establish empathy with the character in problem status; however, they could not name the emotions of that character in relation to these problem statuses accurately (See Table 1). Knowing an emotion being felt brings along the skill of knowing how to hide or change that emotion. This skill is among basic skills that will enable individuals to adapt to their social environment (Southam-Gerow, 2014). When examining the literature; it is seen that children who developed emotional self-regulation skills display fewer behavioral problems and more positive social behaviors (DownsStrand, 2008; Fabes et al., 1999; Garner-Waajid, 2012; Greenspan \& Salmon, 2013; Hill et al., 2006).

In the study, it was determined that the boys tended to receive support from a professional mainly concerning security in their solution to the second problem status, but the girls did not prefer that solution (See Table 2). Ljungberg et al., (2005), Tulviste and Koor, (2005) and Westlund et al., (2008) indicated that gender-specific toys and toy selections were effective on the content of interpersonal conflicts of children and their attitudes towards conflicts. According to the results of the study, solution offers of boys mainly included the concepts of police, police station and security, which supported the relevant literature.

The results of the study showed that while the girls offered more constructive/functional solutions to problem status, the boys tended to abstain from problem status or just preferred to ignore them (See Tables 2, 3, and 5). When examining the literature; it is seen that there are studies claiming that there was no significant difference between the problem solving scores of girls and boys (Dereli-Iman, 2013; Terzi 2003; Yılmaz \& Tepeli, 2013) and also the study results indicating that gender affected problem solving skills (Bukowski, 1990; Musun-Miller, 1993; Walker et al., 2002). These studies which mentioned the effect of gender indicated that girls were better in solving social problems than boys. These results showed a parallelism with results of the 
study. It was seen that the boys in the sample group preferred not to take an active role in solving problems. On the other hand, the girls took responsibility in relation to problem status and tried to contribute to the solution process. The reason for the boys in that group to tend to abstain from problem statuses might be associated with gender roles they perceive. In our culture, girls are treated more protectively, suffer a greater oppression and are mostly deprived of the rights and privileges of boys. This condition caused the girls to regard problems more and take action to solve these problems. It might be thought that this condition caused the boys to disregard problems as a result of privileged attitudes displayed by their adults for them.

Another important result of the study was that the children were able to control negative emotions being felt in relation to problem statuses. For example, the children were able to control their anger (See Table 3) and disappointment (See Table 5), delay the pleasure, and control their emotions and desires (See Table 6). These results indicated that children could perform self-regulation and were compatible with the literature knowledge indicating that self-regulation skills made progresses in the preschool period, especially at age of five (Kochanska, Coy, \& Murray, 2001; Zelazo, Carlson \& Kesek, 2008).

In solutions offered in relation to the second problem status, it was seen that none of the children stated that they would display negative and aggressive attitudes towards their siblings. In solutions offered in relation to the third problem status, on the other hand, it was remarkable that especially three children $(G 4, G 5, B 3)$ thought that the mothers did not allow them to wear the t-shirt considering that their mothers would think that they could feel cold due to the cold weather. These results showed that the children who participated in the study had the skills of theory of mind, which is defined as a skill of understanding other people's desires, intentions and emotions, and making explanations and interpretations in the interaction with people according to these mental statuses (Astington \& Baird, 2005). This condition shows a parallelism with the study by Carlson and Moses (2001) claiming that children around at age of five can use the skills of theory of mind efficiently.

In this study examining how preschool children expressed their emotions in relation to problem statuses, how they generated solutions to problems and whether these solutions differentiated according to gender or not, it was observed that five-year-old children who participated in the study were successful in empathy and selfregulation skills, which are effective on problem solving processes and are also directly associated with the skills of theory of mind. The children were able to establish empathy with the character in problem statuses and view events from his perspective; however, they had difficulty in naming the emotions of that character accurately. In addition, it was observed that while the girls offered more constructive/functional solutions in relation to problem statuses compared to the boys, the boys tended to abstain from problem statuses or just ignored them. These results indicated that both families and educators should pay attention to be more objective while attributing gender roles to children so that gender will not become a disadvantageous factor in children's development and skill acquirement processes. It is also important for educators and primarily parents to emphasize emotions and encourage children to think about their emotions. 


\section{RECOMMENDATIONS}

By the nature of qualitative studies, the results of this study are subjective and can not be generalized (Yıldırım and Şimşek, 2016). However, with these results, it is aimed to give examples to how five-year-old children express their emotions and generate solutions to problems statuses, and contribute to the development of understandings and experiences concerning theory of mind, empathy and self-regulation skills for both readers and other researchers. By considering these results; it is thought that qualitative studies to be conducted in larger sample groups concerning theory of mind, problem solving, empathy and self-regulation skills will help to understand the development processes of these skills better.

\section{ETHICAL TEXT}

In this article, journal writing rules, publishing principles, research and publishing ethics rules, journal ethics rules are followed. In this article, journal writing rules, publishing principles, research and publishing ethics rules, journal ethics rules are followed.

\section{REFERENCES}

Astington, J. W.,\& Baird, J. A. (Eds.). (2005). Why language matters for theory of mind. Oxford University Press.

Astington, J.W. \& Gopnik, A. (1991). Theoretical explanations of children's understanding of the mind. British Journal of Developmental Psychology, 9, 7-31.

Baran, G. \& Erdoğan, S. (2007). A research on perspective taking skills and the social behaviour of six-year-old girls and boys. Pakistan Journal of Social Sciences, 4(2): 236-239.

Bauer, I. M. \& Baumeister, R. F. (2011). Self-regulatory strenght. In K. D. Vohs, R. F. Baumeister (Eds.), Handbook of Self-Regulation: Research, Theory, and Applications. New York: Guilford Press.

Bierman, K. L., Nix, R. L., Greenberg, M. T., Blair, C. \& Domitrovich, C. E. (2008). Executive functions and school readiness intervention: Impact, moderation, and mediation in the Head Start REDI program. Development and Psychopathology, 20, 821-843.

Bondurant, L. M. (2010). The roots of academic underachievement: Prediction from early difficulties with selfregulation. (PhD thesis, The University of Texas), Proquest Information and Learning Company. (UMI 3421467)

Bukowski, W. M. (1990). Age differences in children's memory of information about guests and hosts to peer group entry. Child Development, 62: 1079-1090.

Carlson, S. M. \& Moses, L.J. (2001). Individual differences in inhibitory control and children's theory of mind. Child Development, 72: 1032-1053.

Cole, P. M., Zahn-Waxler, C., Fox, N. A., Usher, B. A. \& Welsh, J. D. (1996). Individual differences in emotion regulation and behavior problems in preschool children. Journal of Abnormal Psychology, 105(4), 518529. 
D’zurilla, T.J., Nezu, A.M. \& Maydeu-Olivares, A. (2004). Social Problem Solving: Theory and Assessment. In E. C. Chang, T. J. D’Zurilla, L. J. Sanna (Eds.), Social problem solving: Theory, research, and training. Retrieved from http://www.ub.edu/gdne/documents/sps chapter_in_APA_book.pdf

Dereli-İman, E. (2013). Cocuklar icin sosyal problem çözme olcegi'nin 6 yaş grubu icin Turkiye uyarlamasi ve okul öncesi davranis problemleri ile sosyal problem cozme becerileri arasindaki iliskiler [Adaptation of social problem solving for children questionnaire in 6 age groups and its relationship with preschool behavior problems]. Kuram ve Uygulamada Egitim Bilimleri, 13(1): 479-498.

Downs, A. \& Strand, P. (2008). Effectiveness of emotion recognition training for young children with developmental delays. Journal of Early and Intensive Behavior Intervention, 5(1): 75-89.

Eskin, M. (2009). Sorun cozme terapisi [Problem solving therapy]. Ankara: HYB Basim Yayin.

Fabes, R. A. \& Eisenberg, N. (1992). Young children's coping with interpersonal anger. Child Development, 63, 116-128.

Fabes, R. A., Eisenberg, N., Jones, S., Smith, M., Guthrie, I., Poulin, R., ... \& Friedman, J. (1999). Regulation, emotionality, and preschoolers' socially competent peer interactions. Child Development, 70(2), 432 442.

Garner, P W. \& Waajid, B. (2012). Emotion knowledge and self-regulation as predictors of preschoolers' cognitive ability, classroom behavior, and social competence. Journal of Psycheducational Assessment, 30(4): 330-343.

Greenspan, S. I. \& Salmon, J. (2013). Meydan okuyan cocuk: Bes tip "guç" cocugu anlama, yetistirme ve onlardan hoslanma [The challenging child: Understanding, raising, and enjoying the five" difficult" types of children]. (Cev. I. Ersevim). İstanbul: Ozgur Yayinlari.

Greenspan, S. I., Wieder, S. \& Simons, R. (2016). Ozel gereksinimli cocuk: Zihinsel ve duygusal gelisim [The child with special needs: Encouraging intellectual and emotional growth]. Cev., I. Ersevim. İstanbul: Ozgur Yayinlari.

Heppner, P.P. \& Krauskopf, C.J. (1987). An information-processing approach to personal problem solving. Counseling Psychologist, 15: 371-447.

Hill, A. L., Degnan, K. A., Calkins, S. D. \& Keane, S. P. (2006). Profiles of externalizing behavior problems for boys and girls across preschool: The roles of emotion regulation and inattention. Developmental Psychology, 42(5), 913-928.

Kochanska, G., Coy, K. C. \& Murray, K. T. (2001). The development of self-regulation in the first four years of life. Child Development, 72: 1091-1111.

Kocak, R. (2002). Aleksitimi: Kuramsal cerceve tedavi yaklasimlari ve ilgili arastirmalar [Alexithymia: Theoretical framework treatment approaches and related researches]. Ankara Universitesi Egitim Bilimleri Fakültesi Dergisi, 35(1-2): 183-212.

Koole, S. L., Van Dillen, L. F. \& Sheppes, G. (2011). The self-regulation of emotion. In K. D. Vohs, R. F. Baumeister (Eds.), Handbook of Self-Regulation: Research, Theory, and Applications. New York: Guilford Press. 
Koksal Akyol, A. \& Didin, E. (2016). Ahlak gelisimi [Moral development]. Cocuk Gelisimi icinde [In Child Development], N. Aral (Ed.). Anadolu Universitesi Yayinlari.

Ljungberg, T., Horowitz, L., Jansson, L., Westlund, K. \& Clarke, C. (2005). Communicative factors, conflict progression, and use of reconciliatory strategies in pre-school boys-a series of random events or a sequential process?. Aggressive Behavior, 31(4): 303-323.

Marvin, R.S., Greenberg, M.T. \& Mossler, D.G. (1976). The early development of conceptual perspective taking: Distinguishing among multiple perspectives. Child Development, 47: 511-514.

McClelland, M. M., \& Tominey, S. L. (2011). Introduction to the special issue on self-regulation in early childhood. Early Education \& Development, 22(3), 355-359.

Merriam, S. B. (2015). Nitel arastirma [Qualitative research] (Cev. Ed. S. Turan). Ankara: Nobel.

Miles, M. B. \& Huberman, A. M. (2015). Nitel veri analizi [Qualitative data analysis]. Cev. Ed,. S. Akbaba Altun, A. Ersoy. Ankara: Pegem.

Montroy, J. J., Bowles, R. P., Skibbe, L. E. \& Foster, T. D. (2014). Social skills and problem behaviors as mediators of the relationship between behavioral self-regulation and academic achievement. Early Childhood Research Quarterly, 29(3), 298-309.

Musun-Miller, L. (1993). Social acceptance and social problem solving in preschool children. Journal of Applied Developmental Psychology, 14, 59-70.

Nota, L., Soresi, S. \& Zimmerman, B. J. (2004). Self-regulation and academic achievement and resilience: A longitudinal study. International Journal of Educational Research, 41(3), 198-215.

Onishi, K. H. \& Baillergeon, R. (2005). Do 15-month-old infants understand false belief?. Science, 308: 255-258.

Raffaelli, M., Crockett, L. J. \& Shen, Y. L. (2005). Developmental stability and change in self-regulation from childhood to adolescence. The Journal of Genetic Psychology, 166(1), 54-76.

Raver, C. C., Li-Grining, C., Bub , K., Jones, S. M., Zhai, F. \& Pressler, E. (2011). CSRP's impact on low-income preschoolers' preacademic skills: self-regulation as a mediating mechanism. Child Development, 82(1), 362-378.

Riggs, N.R., Jahromi, L.B., Razza, R.P., Dillworth-Bart, J.E. \& Mueller, U. (2006). Executive function and the promotion of social-emotional competence. Journal of Applied Developmental Psychology, 27: 300309.

Senemoglu, N. (2007). Gelisim, ögrenme ve ögretim: Kuramdan uygulamaya [Development, learning and teaching: From theory to practice]. Ankara: Gonul Yayincilik.

Smith-Donald, R., Raver, C.C., Hayes, T. \& Richardson, B. (2007). Preliminary construct and concurrent validity of the Preschool Self-regulation Assessment (PSRA) for field-based research. Early Childhood Research Quarterly, 22, 173-187.

Sodian, B. (2011). Theory of mind in infancy. Child Development Perspectives, 5: 39-43.

Southam-Gerow, M.A. (2014). Cocuklarda ve ergenlerde duygusal düzenleme [Emotional regulation in children and adolescents]. Cev. Ed., M. Sahin. Cev., M. Artiran.). Ankara: Nobel.

Taylor, G. J. (2001). Recent developments in alexithymia theory and research. Can J Psychiatry, 45:134-142. 
Terzi, S. (2003). Altıncı sinif ögrencilerinin kisiler arası problem cözme beceri algilari [Interpersonal problem solving skills perceptions of sixth grade students]. Turk Egitim Bilimleri Dergisi, 1(2).

Tulviste, T. \& Koor, M. (2005). "Hands off the car, it's mine!" and "The teacher will be angry if we don't play nicely": Gender-related preferences in the use of moral rules and social conventions in preschoolers' dyadic play. Sex Roles, 53(1): 57-66.

Walker, S., Irving, K. \& Berthelsen, D. (2002). Gender influences on preschool children's social problem-solving strategies. The Journal of Genetic Psychology, 163(2): 197-209.

Wellman, H. (1990). The child's theory of mind. Cambridge, MA: MIT Press

Wellman, H. \& Lagattuta, K.H. (2000). Developing understandings of mind. In S. Baron-Cohen, H. TagerFlusberg, D.J. Cohen (Eds.), Understanding other minds: Perspectives from developmental cognitive neuroscience. Oxford: Oxford University Press.

Westlund, K., Horowitz, L., Jansson, L. \& Ljungberg, T. (2008). Age effects and gender differences on postconflict reconciliation in preschool children. Behaviour, 145(11): 1525-1556.

Yildirim, A. \& Simsek, H. (2016). Sosyal bilimlerde nitel arastirma yontemleri [Qualitative research methods in the social sciences]. Ankara: Seckin.

Yilmaz, E. \& Tepeli, K. (2013). 60-72 Aylik cocuklarin sosyal problem cözme becerilerinin duyguları anlama becerileri acisindan incelenmesi [Examinatıon of social problem solving skills of 60-72 months old children in terms of their emotion understanding skilla]. Turkiye Sosyal Arastirmalar Dergisi, 172(172): 117-130.

Zelazo, P. D., Carlson, S. M. \& Kesek, A. (2008). The development of executive function in childhood. In C. Nelson \& M. Luciana (Ed.), Handbook of developmental cognitive neuroscience (2nd ed., pp. 553-574). Cambridge, MA: MIT Press.

Zimmerman, B. J. (2000). Attaining self-regulation: A social cognitive perspective. In M. Boekaerts, P. R., Pintrich, M. Zeidner (Eds.), Handbook of selfregulation. San Diego, CA: Academic Press. 


\section{ÇOCUKLARIN PROBLEM ÇÖZME BECERILERINE NITEL BIR BAKIŞ}

öz

Problem çözme, bireyin hayata uyum sağlamasını kolaylaştıran, zihin kuramı, empati ve öz düzenleme gibi becerilerle ilişkili bireyin yaşamındaki önemli becerilerden biridir. Problem çözme geliştirilebilen bir beceri olmakla birlikte, erken çocukluk yıllarından itibaren desteklenmesi gerekmektedir. Çocuk ne kadar iyi bir problem çözücü olursa, yaşamanda karşısına çıkacak problemlere o kadar etkin çözümler bulabilecektir. Bu araştırmadaki amaç çocukların problem durumları karşısında nasıl çözümler ürettiklerini ve bu durumlar karşısında hissettikleri duyguları ortaya çıkarmaktır. Araştırmada nitel model ve durum deseni kullanılmıştır. Çalışmanın verileri 2016-2017 eğitim-öğretim yılında Kırklareli Merkez'deki bir anaokuluna devam eden çocuklardan elde edilmiştir. İçerik analizi yapılan çalışmaya gönüllülük esasına göre 11 çocuk dahil edilmiştir. Çalışmaya katılan çocuklardan altısı kız, beşi erkektir. Uygulama sırasında bir kukla ile birlikte beş problem durumu kullanılmıştır. Çocuklarla birebir yapılan uygulamalar sonucunda toplanan veriler, içerik analizi yöntemiyle incelenmiştir. Araştırmanın sonucunda, çocukların problem durumlarına, empati ve öz düzenleme becerilerinin kullanımını içeren etkili çözümler üretebildikleri, ancak problem durumları karşısında hissetikleri duyguları isimlendirmekte zorlandıkları görülmüştür. Araştırmanın sonuçları başta ebeveynler olmak üzere, eğitimcilerin duygular üzerinde daha çok durması ve çocukları duyguları üzerinde düşünmeye teşvik etmesi gerektiğini düşündürmektedir. Ayrıca zihin kuramı, problem çözme, empati ve öz düzenleme becerileri ile ilgili yapılacak daha büyük örneklem gruplu nitel çalışmalar, bu becerilerin gelişim süreçlerinin daha iyi anlaşılmasına yardımcı olabilir.

Anahtar Kelimeler: Problem çözme becerisi, nitel model, duygular. 


\section{Giriş}

Problem çözme bireyin yaşamındaki önemli becerilerden biridir. Heppner ve Krauskopf (1987) problem çözmenin, bireyin gereklilik ve zorluklara uyum sağlayabilmesi için gerekli olan bilişsel ve duyuşsal işlemler dizisi ile davranışsal tepkilerinin olduğunu belirtmiştir. D'Zurilla vd. (2004)'ye göre ise problem çözme, gündelik hayatta karşılaşılan problemlere etkili çözümler bulmak için girişimde bulunulan, bireyin kendisinin oluşturduğu bilişsel-davranışsal bir süreç olarak tanımlanır. Geliştirilebilen bir beceri olan problem çözme becerisi, bireyin içinde yaşadığı çevreye uyum sağlamasına yardım eder (D’zurilla vd., 2004). Bu nedenle çocukların, okul öncesi dönemden itibaren problem çözme becerilerine sahip olması, gerçek hayata uyum sağlamaları açısından son derece önemlidir. Çocuk ne kadar iyi bir problem çözücü olursa, karşısına çıkacak problemlere o kadar etkin çözümler bulabilecektir.

Problem çözme sürecini etkileyen pek çok faktör bulunmaktadır. Zihin kuramıyla ilişkili olan öz düzenleme ve empati yeteneği bu faktörlere örnek olarak verilebilir. İnsanların istek, niyet, duygularını anlama ve insanlarla olan etkileşiminde bu zihinsel durumlara göre açıklama ve yorumlama getirebilme becerisi olarak tanımlanan zihin kuramı becerine (Astington \& Baird, 2005) sahip bireyler; diğer insanların farklı bir zihin yapısına, bilgi ve deneyime sahip olduğunu fark ederler. Zihin kuramına ilişkin belirtiler ortalama bir yaş civarında ortaya çıkmakta (Onishi \& Baillergeon, 2005; Sodian, 2011), dört yaşında önemli bir gelişme göstermekte (Astington \& Gopnik, 1991; Wellman, 1990; Wellman \& Lagattuta, 2000) ve beş yaş civarında yetişkinlerinkine benzer bir hale gelmektedir (Carlson \& Moses, 2001). Bu gelişim öz düzenleme becerinde görülen gelişimle de paraleldir (Kochanska, Coy, \& Murray, 2001). Zimmerman (2000)'a göre öz düzenleme; bireyin bilişsel, motivasyonel ve davranışsal olarak öğrenme sürecini kontrol etmesi anlamına gelirken, aynı zamanda bireyin davranış, eğilim ve isteklerini erteleyebilme ya da bastırabilme, duygularını kontrol edebilme ve düzenleyebilme, hem içsel hem de dışsal taleplere etkili ve yerinde cevaplar/tepkiler verebilmesi olarak tanımlanmaktadır (Bauer \& Baumeister, 2011; Koole, Van-Dillen \& Sheppes, 2011; Raffaelli, Crockett \& Shen 2005). Araştırmacılar öz düzenlemenin, başkalarının zihinlerini anlama becerisini desteklediğini (Riggs vd., 2006) ve sonucunda sosyal davranışları etkileyebileceğini belirtmektedirler (Bierman vd., 2008; Fabes \& Eisenberg, 1992; Montroy vd., 2014). Öz düzenleme becerisi gelişmemiş çocukların akran reddi (McCelland ve Tominey, 2011; Montroy vd., 2014) ve akademik zorluklar yaşadıkları da bilinmektedir (Bondurant, 2010; Nota vd., 2004; Smith-Donald vd., 2007).

Bir bireyin, karşılaştığı problemin ç̧̈zümüyle ilgilenmesi, kişilik özellikleri ile problemin özellikleri arasındaki örtüşmeye bağlıdır (Eskin, 2009). Kişilik yapısı kavramı altında sayabileceğimiz empati kurma yeteneği sayesinde birey, başkalarının duygu, düşünce ve davranışlarını anlayabilir, kendini onların yerine koyarak, onları oldukları gibi kabullenebilir ve davranışlarına saygı gösterebilir (Köksal Akyol \& Didin, 2016). Strayer ve Robert (2004)'e göre başkasının duygularını ve bakış açısını daha iyi anlayan empatik çocuklar, sosyal problem çözmede, çatışma ve öfke olaylarını azaltmada daha başarıııdırlar.

Diğer insanlardan alınan uyarıları duygusal olarak yorumlayabilmek, duyguların farkında olmayı ve duyguları doğru anlamayı gerektirir. Duygular doğru anlaşılmadığında çocuklar bir karmaşa içinde olurlar ve doğru yerde doğru tepkiler vermede güçlük yaşarlar (Greenspan, Wider ve Simon, 2016). Duyguların farkında olma ve 
anlama süreçlerinde yaşanan zorluklar, çocukların öz düzenleme becerilerini de olumsuz etkileyebilir ve dolayısıyla sosyal davranışları üzerinde yıkıcı etkiler doğurabilir (Riggs, vd., 2006). Çocuklar duygularını ifade edemediklerinde şiddet eğilimleri de artar. Şiddete eğilimli birçok çocuk ve gencin ise duygularını tanımlayamadıkları ve davranışlarının sonuçlarını öngöremedikleri belirtilmektedir (Greenspan ve Salmon, 2013). İçinde bulunduğu durum karşısında hissettiği duyguyu net ve doğru bir şekilde isimlendirebilen çocuklar bu duyguyla baş edebilmek için neler yapması gerektiği hakkında daha yeterli olurlar. Örneğin kendini mutsuz hisseden bir çocuk, hissettiği bu duyguyu doğru adlandırabildiğinde ve üzüntüsünün kaynağını bildiğinde, içinde bulunduğu durumu değiştirmek, üzüntüsünü azaltmak ve hissettiği duyguyu değiştirmek için harekete geçebilir. Bu işleme duygusal düzenleme adı verilir (Southam-Gerow, 2014) ve öz düzenleme kavramı içinde yer alır (McClelland ve Tominey, 2014).

Sosyal öğrenme kuramına göre, bireyler, davranış tarzlarını, duygu, düşüncelerini ifade ediş biçimlerini ve iletişim yapılarını, içinde bulundukları sosyal-kültürel çevrede şekillendirirler (Senemoğlu, 2007). Sosyal-kültürel çevreyi oluşturan okul ve aile üyeleri, çocukların duygu ve düşüncelerini ifade etme becerilerini desteklemediğinde, duygular üzerine konuşmadığında ve duygularını bastırmaya yönelttiğinde, çocukların, duygularının farkında olmayan ve duygularını ifade etmede zorlanan bireyler olmalarına neden olabilirler. Yapılan araştırmalar, bireylerin, duygularını ifade edebilme ve duygularının farkında olarak onları kontrol edebilmelerini içeren duygusal düzenlemede çocukluktan itibaren gelişim süreçlerindeki yaşantıların ve öğrenmelerin etkili olduğunu vurgulamaktadır (Koçak, 2002). İlgili literatür incelendiğinde, okul öncesi çocuklarda duygusal öz düzenleme ile dışsallaştırılmış davranış problemleri arasında ilişki olduğunu (Hill vd., 2016), akranlarının duygularını daha iyi anlayan, tanıyan ve doğru ifade edebilen çocukların daha olumlu sosyal davranışlar sergilediğini (Downs-Strand, 2008; Fabes vd., 1999; Garner-Waajid, 2012), duygularını ifade etmede zorlanan çocuklarda anksiyete ve depresif özellikler görüldüğünü gösteren araştırmalara rastlanmıştır.

Yaşları ne olursa olsun bireyler, günlük yaşamla ilgili çözmek zorunda kalacakları pek çok problemle karşılaşırlar. Bu problemler kişilerin sosyal uyumlarını etkileyeceğinden; öğrenilen ve geliştirilebilen bir beceri olan problem çözme becerisinin küçük yaşlardan itibaren desteklenmesi son derece önemlidir. Yaşanan problemlerin çözülmesinde, ne gibi yollar izlendiği ve nelere önem verildiği, çözüm yolunun etkililiğini belirleyecektir. Problem çözmeye çalışırken, esnek davranabilmek, duyguları kontrol edebilmek ve düzenleyebilmek, taleplere etkili ve yerinde cevaplar/tepkiler verebilmek, karşıdakinin bakış açısı ile olaya bakabilmek, problemin üstesinden gelebilmek için son derece önemli becerilerdir. Etkili problem çözmek için, gerekli olduğu düşünülen tüm bu beceriler, zihin kuramı çerçevesinde, öz düzenleme ve empati becerileri ile ilişkilidir. Bu konuda yapılmış olan araştırmalar çocukların problem çözme becerilerinde ne kadar başarılı olduklarına odaklanırken (Dereliİman, 2013; Yılmaz \& Tepeli, 2013) bu araştırmada çocukların problem çözme sürecinde nasıl çözümler ürettikleri üzerinde durulmuştur. Bu bakış açısı ile yola çıkılan bu çalışmada şu sorulara yanıt aranmıştır:

1. Çocuklar problem durumları karşısında duygularını nasıl ifade ederler?

2. Çocuklar problem durumlarına nasıl çözümler üretirler?

3. Çocukların problem durumlarına ürettikleri çözümler cinsiyete göre nasıl farklılık göstermektedir? 


\section{YÖNTEM}

\section{Araștırmanın Modeli}

Okuyucular ve diğer araştırmacılar için, beş yaş çocuklarının problem durumlarına ürettikleri çözümlere örnekler ortaya koyabilmek, zihin kuramı, empati ve özdüzenleme becerilerine ilişkin anlayış ile deneyimlerin gelişmesine katkıda bulunabilmek amacıyla bu araştırma, nitel modelde tasarlanmış ve durum deseni kullanılmıştır. Durum çalışması sınırlı bir sistemin derinlemesine incelenmesini gerektirir. Güncel bir olguyu gerçek hayattaki bağlantısıyla ilişkilendirir (Merriam, 2015). Burada ele alınan durum çocukların problem çözme becerisidir. Durum çalışması yaparken izlenen aşamalar şu şekildedir: Araştırma sorularının geliştirilmesi, araştırmanın alt problemlerinin geliştirilmesi, analiz birimini saptanması, çalışılacak durumun belirlenmesi, araştırmaya katılacak bireylerin seçimi, verilerin toplanması ve toplanan verinin alt problemlerle ilişkilendirilmesi, verilerin analiz edilmesi ve yorumlanması ve durum çalışmasının raporlaştırılması sürecidir (Yıldırım ve Şimşek, 2016). Bu araştırmadaki süreç şu şekildedir:

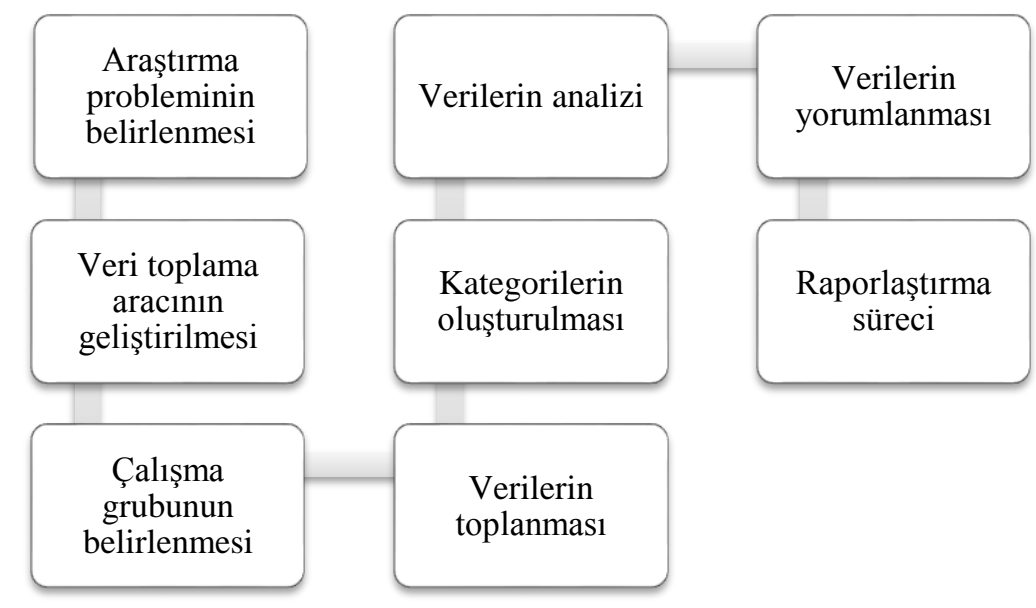

Şekil 1. Veri Analiz Sürecini Gösteren Akış Planı

\section{Çalısma Grubu}

Çalışmanın verileri 2016-2017 eğitim-öğretim yılında Kırklareli Merkez'deki bir anaokuluna devam eden çocuklardan elde edilmiştir. Araştırmanın çalışma grubu için seçkisiz olmayan örnekleme yöntemlerinden uygun örnekleme yöntemi kullanılmıştır. Araştırmanın çalışma grubunu beş yaşındaki 11 çocuk oluşturmuştur. Çalışmaya katılan çocuklardan altısı kız, beşi erkektir. Bir erkek çocuk, ilk problem durumundan sonra devam etmek istemediğini belirttiğinden sınıfına dönmüştür. Veriler 01.04.2017- 30.04.2017 tarihleri arasında toplanmıştır.

\section{Verilerin Toplanması}

Bu çalışmada veriler görüşme tekniği kullanılarak toplanmıştır. Görüşme önemli bir bilgi toplama aracıdır. Katılımcının bakış açısını, niyetini, duygu ve düşüncelerini öğrenmek için de önemli bir kaynaktır (Merrriam, 
2015). Çocuklarla görüşme yapmadan önce araştırmacılar tarafından bir görüşme formu geliştirilmiştir. Öncelikle beş farklı problem durumu oluşturulmuştur. Problem durumlarının ana kahramanı olan Çiko adındaki çocuk için bir kukla tasarlanmıştır. Kukla, çocuklar için süreci daha keyifli hale getirmek ve çocukların daha rahat özdeşim kurmaları amacıyla oluşturulmuştur. Tasarlanan kuklanın yönlendirici olmaması için belirgin bir cinsiyet ayrımı yapılmamıştır. Ayrıca kuklada ifadesiz bir yüz olmasına dikkat edilmiştir (Görsel 1.).

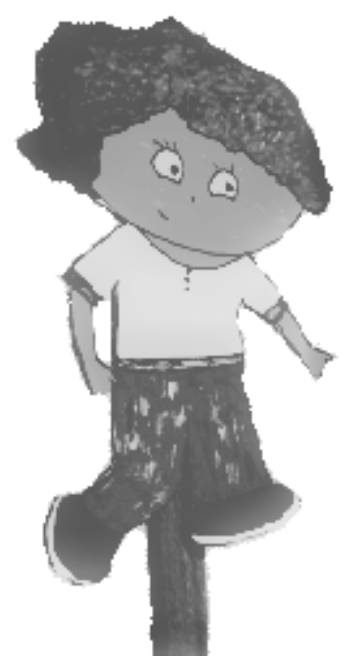

Görsel 1. Problem Durumları için Kullanılan Kukla

Görüşme sırasındaki eksikliklerin, anlaşılmazlıkların ortaya çıkarılması için iki çocukla pilot çalışma yapılmıştır. Pilot çalışmaya alınan çocuklar, bir kız bir erkek olarak seçilmiştir. Her çocukla ayrı ayrı çalışılmış ve Çiko tanıtıldıktan sonra her problem durumu sırayla okunmuş, çocukların cevapları, uygulayıcı ve çocuğu dinleyen bir diğer araştırmacı tarafından kayıt altına alınmıştır. Çiko çocuklara şu şekilde tanıtılmıştır: "Bu Çiko. Çiko beş yaşında ve anaokuluna gidiyor. Çiko'nun da her çocuk gibi karşılaştığı bazı sorunlar var. Haydi, şimdi onun neler yaşadığına bakalım ve ona yardımcı olalım." Pilot çalışma sonrasında soru ifadelerinde düzeltmeler yapılmış ve gerektiğinde ek sorular sorularak çocukların açıklama yapmalarına olanak sağlanmıştır. Her problem durumu sonrasında çocuklara aynı sorular sorulmuştur (Çiko bu durumda ne hissetmiş olabilir?, Çiko bu durumda ne yapabilir?). Araştırma kapsamında sorulan sorular dikkate alındığında çocuklarla yapılan görüşmenin yarı yapılandırılmış görüşme olduğu söylenebilir. Yarı yapılandırılmış görüşmede sorular açık uçludur, fakat görüşme keşfedilmesi gereken konuların açığa çıkarılması için sorular ya da bir konu tarafından yönlendirilir. Açık uçlu sorular yoluyla yeni fikirlerin oluşmasına ortam hazırlanır (Merriam, 2015). Bu çalışmada da çocukların problem durumlarına farklı çözümler üretmeleri beklenmiştir.

\section{Verilerin Analizi}

Görüşme tekniği kullanılarak toplanan veriler içerik analizi yoluyla değerlendirilmiştir. İçerik analizi için çocukların cevapları doğrultusunda kategoriler oluşturulmuştur. Kategori oluşturma bir veri analizidir ve veri toplama esnasında oluşturulmaya başlanmalıdır. Kategoriler araştırma sorularına cevap verebilir nitelikte olmalıdır (Merrriam, 2015). Bu çalışma için oluşturulan kategoriler her problem durumu için 11 çocuğun verdiği 
cevaplar değerlendirilerek oluşturulmuştur. Dolayısıyla her problem durumu için farklı kategoriler ortaya çıkmışır.

Araştırmanın geçerliliğini arttırmak amacıyla her problem durumuna ait tablonun altına çocukların cevaplarından doğrudan alıtılara yer verilmiştir. Veri analizinin güvenirliği Miles ve Huberman'ın (2015) [Görüş birliği/ (Görüş birliği + Görüş ayrılığı) X 100] formülü kullanılarak hesaplanmıştır. Buna göre iki araştırmacı tüm problem durumlarına ait tabloları birlikte oluşturmuş ve $\% 100$ güvenirlik sağlanmıştır.

\section{Araştırmacının Rolü}

Görüşme yapılan çocuklar gönüllülük esasına göre seçilmiştir. Sınıfta çocuklara araştırmanın kapsamı genel hatlarıyla ifade edilmiş, görüşme sırasında problem durumlarını içeren metinlerin okunacağı belirtilmiştir. Çalışmaya katılmak isteyen çocuklar boş bir sınıfa sırayla alınarak uygulama gerçekleştirilmiştir. Uygulama öncesinde çocukla tanışılıp kısa bir sohbet edildikten sonra, kukla ortaya çıkarılmış ve çocukla tanıştırılmışır. Uygulamanın mümkün olduğunca oyun havasında sürdürülmesine özen gösterilmiştir. Ilgisi dağılan çocuk olduğunda ek sorularla konuya dönüş yapılmış, süreci yarıda bırakmak isteyen bir erkek çocuk sınıfına dönmüş ve çalışma için zorlanmamıştır. Çalışmaya katılan tüm çocuklara isimleri yerine birer kod verilmiştir. Ayrıca kız çocuklar için $\mathrm{K}$, erkek çocuklar için E kodu kullanılarak numaralandırma yapılmıştır.

\section{BULGULAR}

Araştırmada elde edilen bulgular tablolar halinde sunulmuştur.

Tablo 1. Çocukların Problem Durumları Karşısında Belirttikleri Duygular

\begin{tabular}{|c|c|c|c|c|c|c|c|c|c|c|c|}
\hline & K1 & K2 & K3 & K4 & K5 & K6 & E1 & E2 & E3 & E4 & E5 \\
\hline I. & 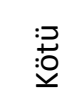 & 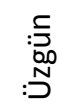 & . & 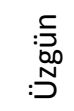 & $\begin{array}{l}\text { zे } \\
\underline{\underline{y}}\end{array}$ & , & $\begin{array}{l}\stackrel{c}{0.0} \\
\stackrel{N}{\underline{N}}\end{array}$ & 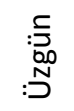 & 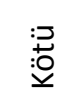 & ' & $\frac{\bar{z}}{\underline{\bar{z}}}$ \\
\hline $\begin{array}{c}\text { II. } \\
\text { Problem Durumu }\end{array}$ & 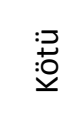 & $\begin{array}{l}\stackrel{ᄃ}{\overline{0}} \\
\stackrel{N}{\underline{N}}\end{array}$ & $\begin{array}{l}: 5 \\
: \stackrel{5}{0} \\
: \stackrel{1}{\supset}\end{array}$ & 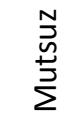 & $\begin{array}{l}: 5 \\
: \stackrel{5}{D} \\
: \stackrel{D}{D}\end{array}$ & $\begin{array}{l}: 5 \\
: \stackrel{5}{D} \\
: \stackrel{0}{D}\end{array}$ & $\begin{array}{l}\stackrel{c}{0.0} \\
\stackrel{N}{\underline{N}}\end{array}$ & 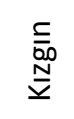 & $\begin{array}{l}\vec{z} \\
\underline{\dot{y}}\end{array}$ & 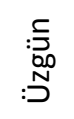 & $\begin{array}{l}\frac{c}{00} \\
\stackrel{N}{\underline{N}}\end{array}$ \\
\hline $\begin{array}{l}\text { III. } \\
\text { Problem Durumu }\end{array}$ & $\begin{array}{l}:= \\
: 0 \\
: 0 \\
: 0\end{array}$ & 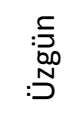 & 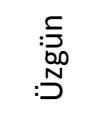 & \begin{tabular}{l}
$N$ \\
\multirow{3}{N}{} \\
$\stackrel{5}{5}$ \\
$\sum$ \\
$\sum$
\end{tabular} & 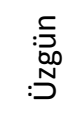 & 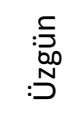 & $\begin{array}{l}\frac{c}{00} \\
\frac{N}{\underline{N}}\end{array}$ & 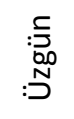 & : & 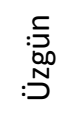 & , \\
\hline $\begin{array}{c}\text { IV. } \\
\text { Problem Durumu }\end{array}$ & 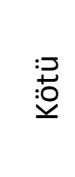 & 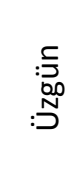 & 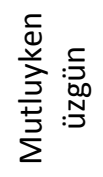 & \begin{tabular}{l}
$N$ \\
\multirow{3}{N}{} \\
$\stackrel{5}{5}$ \\
$\sum$
\end{tabular} & 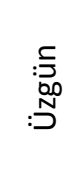 & $\begin{array}{l}: 5 \\
: \stackrel{5}{D} \\
: \stackrel{5}{D}\end{array}$ & 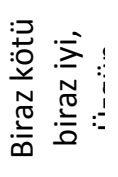 & $\begin{array}{l}\stackrel{\check{0}}{\mathrm{D}} \\
\frac{\mathrm{N}}{\mathrm{y}}\end{array}$ & $\begin{array}{l}: \overline{7} \\
: 0 \\
: 0\end{array}$ & 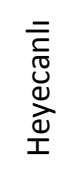 & 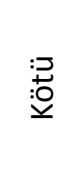 \\
\hline $\begin{array}{c}\text { V. } \\
\text { Problem Durumu }\end{array}$ & $\frac{\overline{\frac{v}{\pi}}}{\frac{\pi}{2}}$ & 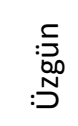 & 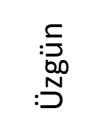 & 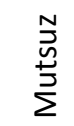 & : & : & 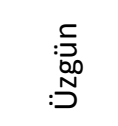 & , & 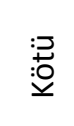 & ' & $\begin{array}{l}\text { 韋 } \\
\text { 总 }\end{array}$ \\
\hline
\end{tabular}


Tablo 1 incelendiğinde çocukların Çiko ile empati kurabildikleri ve Çiko'nun perspektifinden olaylara bakabildikleri ancak, bu problem durumları karşısında Çiko'nun hissettiği duyguları doğru olarak isimlendiremedikleri görülmüştür. Örneğin hayal kırıklığına uğrama duygusu, iki çocuk tarafından "mutluyken üzgün” (K3) ve "biraz kötü, biraz iyi, üzgün” (E1) ifadeleri ile açıklanmaya çalışılmıştır.

Tablo 2. Çocukların Birinci Problem Durumuna Yönelik Ürettikleri Çözüm Önerileri

Çiko bir tatil günü annesiyle alışverişe gitti. Birlikte dükkânları gezerlerken Çiko kocaman bir oyuncak I. ayı gördü. Koşarak dükkâna giden Çiko, oyuncak ayıyla oynamaya başladı. Sonra oyuncağı annesine Problem göstermek için döndüğünde annesinin yanında olmadığını gördü. Çiko bu durumda ne yapabilir?

Durumu Çevreden Annesini Güvenlik/polise Telefonla Oyalanma

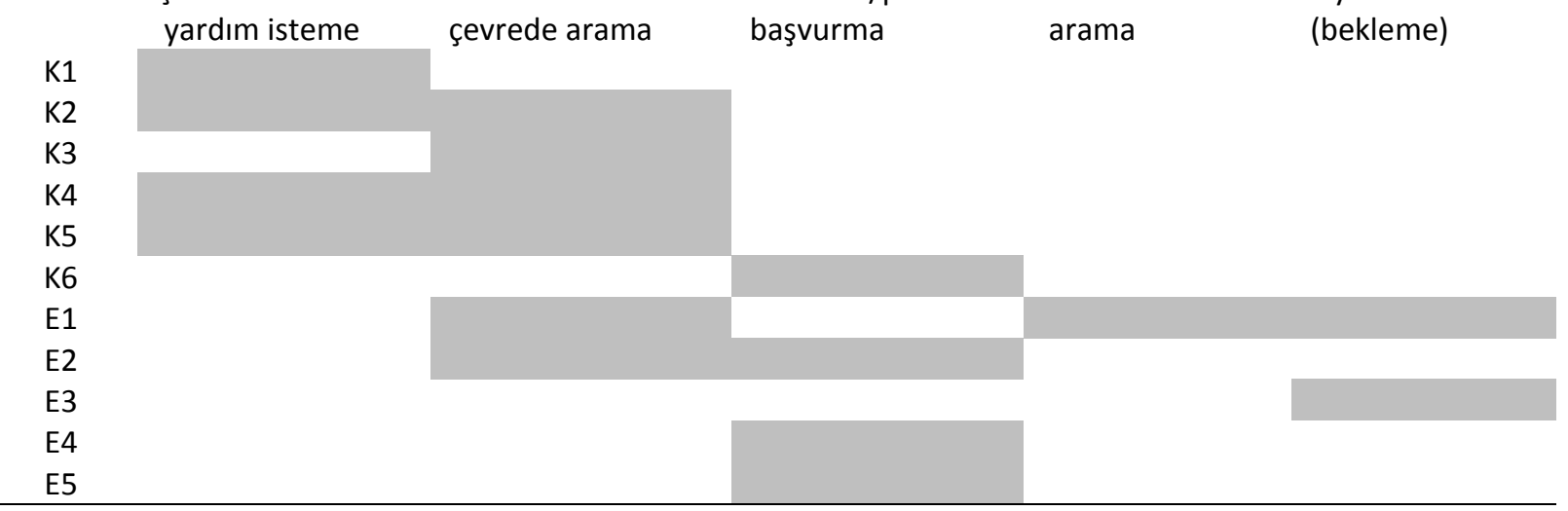

Tablo 2 incelendiğinde, erkeklerin problem durumuna yönelik ürettikleri çözümlerde daha çok güvenlik konusunda bir profesyonelden destek almaya eğilimli oldukları, ancak bir kız hariç diğer tüm kızların bu çözümü tercih etmedikleri dikkat çekmektedir. Örneğin E5 çözüm olarak "Karakola gidebilir”; E2 “... Polisin numarasını biliyorsa polisi arar." derken, K1 "Yardım çağırabilir, kasaya gidip annem nerede diye sorabilir, onlar onu yönlendirebilir." demiştir. Cevaplarda dikkat çeken bir başka nokta da, bazı erkek çocuklarının problem durumunu görmezden gelmesidir. Örneğin E3 bu problem durumuna çözüm olarak; “Oyuncakla oynasın, televizyon seyretsin, resim yapsın. Annesi belki markette çay içiyordur." demiştir.

Tablo 3. Çocukların İkinci Problem Durumuna Yönelik Ürettikleri Çözüm Önerileri

\begin{tabular}{|c|c|c|c|c|}
\hline \multirow{2}{*}{$\begin{array}{l}\text { II. } \\
\text { Problem } \\
\text { Durumu }\end{array}$} & \multicolumn{4}{|c|}{$\begin{array}{l}\text { Çiko'ya babası doğum gününde en sevdiği problem durumu kitabını aldı. Çiko onu okuduktan sonra } \\
\text { kitaplığındaki ön sıraya yerleştirdi. Her fırsatta yeni kitabına bakıp mutlu oluyordu. Yine bir gün } \\
\text { kitabına bakmak için odasına girdiğinde küçük kardeşinin kitabıyla oynarken sayfaları yırttığını gördü. } \\
\text { Çiko bu durumda ne yapabilir? }\end{array}$} \\
\hline & Yenisini alma & $\begin{array}{l}\text { Kardeşinin } \\
\text { ulaşamayacağı } \\
\text { bir yere kaldırma }\end{array}$ & $\begin{array}{l}\text { Kardeşini } \\
\text { oyalama }\end{array}$ & $\begin{array}{l}\text { Kardeşinden } \\
\text { yenisini } \\
\text { bekleme }\end{array}$ \\
\hline \multicolumn{5}{|l|}{ K1 } \\
\hline \multicolumn{5}{|l|}{$\mathrm{K} 2$} \\
\hline \multicolumn{5}{|l|}{ K3 } \\
\hline \multicolumn{5}{|l|}{ K4 } \\
\hline \multicolumn{5}{|l|}{ K5 } \\
\hline \multicolumn{5}{|l|}{ K6 } \\
\hline \multicolumn{5}{|l|}{ E1 } \\
\hline \multicolumn{5}{|l|}{ E2 } \\
\hline \multicolumn{5}{|l|}{ E3 } \\
\hline \multicolumn{5}{|l|}{ E4 } \\
\hline E5 & & & & \\
\hline
\end{tabular}


Tablo 3 incelendiğinde, kızların problem durumu karşısında onarma ve yenisi alma gibi daha yapıcı/işlevsel çözümler sundukları görülürken, erkeklerin problem durumlarından kaçınmaya eğilimli oldukları belirlenmiştir. Erkekler problemin çözümüne yönelik aktif rol almamayı tercih etmektedirler. Örneğin E1 bu probleme çözüm olarak "Baba, kardeşim kitabımı yırttı diyebilir. Neden yaptın demiştir, kardeşi kıskandım yırttım demiştir. Kitabı yüksek bir yere koyar, kardeşine başka bir şey verir onunla oynar." demiştir. Buna karşın bir kızın sunduğu çözüm ise şu şekildedir (K6); "Yapıştırabilir, zımbalayabilir, tamir edebilir." Ya da bir başka kız (K4), "O sayfaları alıp yapıştırabilir." demiştir.

Tablo 4. Çocukların Üçüncü Problem Durumuna Yönelik Ürettikleri Çözüm Önerileri

\begin{tabular}{|c|c|c|c|c|c|c|c|c|}
\hline \multirow[b]{2}{*}{$\begin{array}{l}\text { III. } \\
\text { Problem } \\
\text { Durumu }\end{array}$} & \multicolumn{8}{|c|}{$\begin{array}{l}\text { Çikonun çok sevdiği bir arkadaşının doğum günü partisi vardı. Çiko partiye giderken kısa kollu yeşil } \\
\text { tişörtünü giyerek gitmek istedi. Annesi buna karşı çıktı. Çiko'nun o tişörtle doğum günü partisine } \\
\text { gitmesine izin vermedi. Çiko bu durumda ne yapabilir? }\end{array}$} \\
\hline & $\begin{array}{l}\text { Rica } \\
\text { etme }\end{array}$ & $\begin{array}{l}\text { Annenin } \\
\text { nedenine } \\
\text { göre } \\
\text { çözüm } \\
\text { üretme }\end{array}$ & $\begin{array}{l}\text { Uzun kollu } \\
\text { giyinme/ } \\
\text { üzerine bir } \\
\text { şey giyme }\end{array}$ & $\begin{array}{l}\text { Gitmekten } \\
\text { vazgeçme }\end{array}$ & $\begin{array}{l}\text { Gizlice } \\
\text { giyinme }\end{array}$ & $\begin{array}{l}\text { Başka } \\
\text { bir } \\
\text { tişört } \\
\text { giyme }\end{array}$ & $\begin{array}{l}\text { Israr } \\
\text { etme }\end{array}$ & $\begin{array}{l}\text { Anneyle } \\
\text { pazarlık } \\
\text { yapma }\end{array}$ \\
\hline K1 & & & & & & & & \\
\hline K2 & & & & & & & & \\
\hline K3 & & & & & & & & \\
\hline K4 & & & & & & & & \\
\hline K5 & & & & & & & & \\
\hline K6 & & & & & & & & \\
\hline E1 & & & & & & & & \\
\hline E2 & & & & & & & & \\
\hline E3 & & & & & & & & \\
\hline E4 & & & & & & & & \\
\hline E5 & & & & & & & & \\
\hline
\end{tabular}

Tablo 4'te kızların belirtilen problem durumu karşısındaki isteklerine 'rica ederek' ulaşmaya çalıştıkları ancak; erkeklerin pazarlık ve ısrar yolunu tercih ettikleri görülmektedir. Örneğin K3 "Annesini ikna edebilir, lütfen der. Annesi sevmediklerini zorla giydirmesin." derken, E1 "Yaz gelince giyer o tişörtü. Annesine gidip yaz gelince giydirecek misin o tişörtü? demiştir." şeklinde bir açıklama yapmıştır. Araştırmanın bir diğer önemli bulgusu ise; üç çocuğun problem durumu karşısında kendiliğinden neden-sonuç ilişkisi kurmalarıdır. Örneğin K4 “Neden diye sorsun, nedenini öğrensin. Üşüyorsa üzerine hırka giyebilir ya da kollarını birleştirip kendini sarabilir" derken; K5 “Üzerine mont giyebilir." demiştir.

Tablo 5. Çocukların Dördüncü Problem Durumuna Yönelik Ürettikleri Çözüm Önerileri

\begin{tabular}{|c|c|c|c|c|c|}
\hline \multirow{2}{*}{$\begin{array}{l}\text { IV. } \\
\text { Problem } \\
\text { Durumu }\end{array}$} & \multicolumn{5}{|c|}{$\begin{array}{l}\text { Çiko babasıyla hafta sonu tatili için eğlenceli bir plan yapmıştı ve heyecanla o günün gelmesini } \\
\text { bekliyordu. Ama sonra babasının önemli bir işi çıktığını öğrendi. Çiko bu durumda ne yapabilir? }\end{array}$} \\
\hline & Yeni plan yapma & $\begin{array}{l}\text { Eski planda } \\
\text { Israrcı olma }\end{array}$ & $\begin{array}{l}\text { Kendisinin } \\
\text { gizli gitmesi }\end{array}$ & $\begin{array}{l}\text { Babasını } \\
\text { bekleme }\end{array}$ & Umursamama \\
\hline K1 & & & & & \\
\hline $\mathrm{K} 2$ & & & & & \\
\hline K3 & & & & & \\
\hline K4 & & & & & \\
\hline K5 & & & & & \\
\hline K6 & & & & & \\
\hline
\end{tabular}




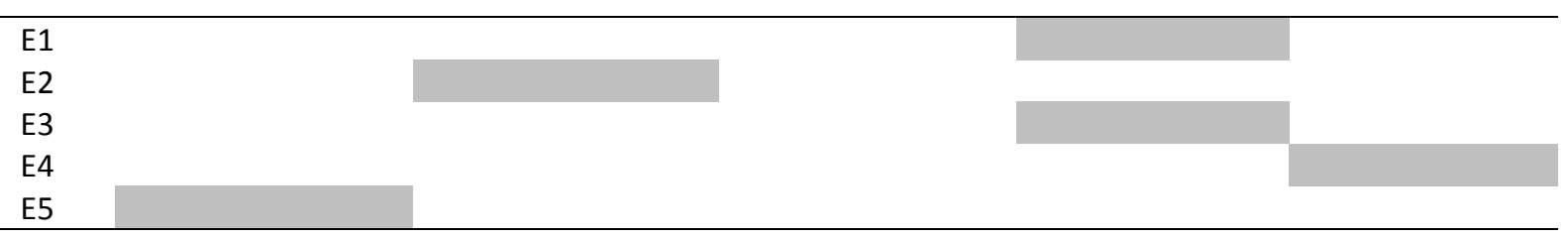

Tablo 5 incelendiğinde kızların problem durumu karşısında yenilik arayışına girdikleri ve alternatif yollar üretebildikleri görülürken, erkeklerin, probleme çözüm olacak yeni durumlara yönelmede zorlandıkları görülmektedir. Örneğin K1 “... Annesiyle plan yapar. Babasının işe gitmesine izin verir. Ya da evde oyun oynar.”; K5 “Babası olmadan başka bir yere gitsin. Eve başka bir şeyler yapmaya giderdim. Anneme güzel bir resim yapardım." derken; E1 çözüm olarak "Babasını beklemiştir, gelince oynamışlardır."; E2 ise "Israr ederse belki babası götürür..." demiştir.

Tablo 6. Çocukların Beşinci Problem Durumuna Yönelik Ürettikleri Çözüm Önerileri

\begin{tabular}{|c|c|c|c|c|}
\hline \multirow{2}{*}{$\begin{array}{l}\text { V. } \\
\text { Problem } \\
\text { Durumu }\end{array}$} & \multicolumn{4}{|c|}{$\begin{array}{l}\text { Annesi Çiko için bir yaz günü çikolatalı dondurma hazırlamıştı. Dondurmanın hazır hale gelmesi için } \\
\text { buzlukta akşama kadar beklemesi gerekiyordu. Ama Çiko dondurmayı hemen yemek istiyordu. } \\
\text { Çiko bu durumda ne yapabilir? }\end{array}$} \\
\hline & $\begin{array}{l}\text { Bir etkinlikle oyalanma (Oyun } \\
\text { oynama, resim yapma, kitap } \\
\text { okuma, TV izleme, uyuma) }\end{array}$ & $\begin{array}{l}\text { Hızlı donmasını } \\
\text { sağlama }\end{array}$ & Bekleme & $\begin{array}{l}\text { Hazır dondurma } \\
\text { alma }\end{array}$ \\
\hline \multicolumn{5}{|l|}{ K1 } \\
\hline \multicolumn{5}{|l|}{ K2 } \\
\hline \multicolumn{5}{|l|}{ K3 } \\
\hline \multicolumn{5}{|l|}{ K4 } \\
\hline \multicolumn{5}{|l|}{ K5 } \\
\hline \multicolumn{5}{|l|}{ K6 } \\
\hline \multicolumn{5}{|l|}{ E1 } \\
\hline \multicolumn{5}{|l|}{ E2 } \\
\hline \multicolumn{5}{|l|}{ E3 } \\
\hline \multicolumn{5}{|l|}{ E4 } \\
\hline E5 & & & & \\
\hline
\end{tabular}

Tablo 6 incelendiğinde, çocukların problem durumundaki gibi, beklemelerini gerektiren bir durum karşısında genel anlamda kendi kendilerini telkin edebildikleri, hazzı erteleyebildikleri ve ısrarcı olmadıkları görülmüştür. Örneğin K1 "Uyuyabilir, oyun oynayabilir, annesi ile televizyon izleyebilir." derken E1 “Akşama kadar bekleyip yememiştir, sabırla beklemiştir." ve E5 ise "Aklından silecek bir şey yapabilir. Sonra akşam hatırlar. Oyun oynayabilir, babasıyla iş yerine gidebilir, vakit geçirebilir." demiştir.

\section{SONUÇ ve TARTIŞMA}

Bu araştırmada, okul öncesi dönemde çocukların problem durumları karşısında duygularını nasıl ifade ettikleri, problemlere nasıl çözümler ürettikleri ve bu çözümlerin cinsiyete göre farklılaşıp farklılaşmadığı incelenmiştir. Araştırmada elde edilen bulgular özetlenerek aşağıda sunulmuştur.

Araştırmanın sonucunda çocukların problem durumundaki karakterle empati kurabildikleri, ancak bu problem durumları karşısında karakterin hissettiği duyguları doğru isimlendiremedikleri görülmüştür (Bkz. Tablo1). 
Hissedilen duygunun ne olduğunun bilinmesi, hissedilen bu duygunun nasıl saklanabileceğini veya nasıl değiştirebileceğini bilme becerisini de beraberinde getirir. Bu beceri bireylerin sosyal çevrelerine uyumunu sağlayacak temel becerilerdendir (Southam-Gerow, 2014). Literatüre bakıldığında duygusal öz düzenleme becerisi gelişmiş olan çocukların daha az davranış problemleri gösterdikleri ve daha olumlu sosyal davranışlarda bulundukları görülmektedir (Downs-Strand, 2008; Fabes vd., 1999; Garner-Waajid, 2012; Greenspan ve Salmon, 2013; Hill vd., 2006).

Araştırmada erkeklerin ikinci problem durumuna yönelik ürettikleri çözümlerde daha çok güvenlik konusunda bir profesyonelden destek almaya eğilimli oldukları, ancak kızların bu çözümü tercih etmedikleri bulunmuştur (Bkz. Tablo2). Ljungberg vd. (2005), Tulviste ve Koor, (2005) ve Westlund vd. (2008), çocukların yaşadıkları kişilerarası çatışmaların içeriğinde ve çatışmalar karşısındaki tutumlarında, cinsiyete özel oyunlarının ve oyuncak seçimlerinin etkili olduğunu belirtmektedirler. Araştırma sonuçlarına göre, erkeklerin çözüm önerilerinde daha çok polis, karakol ve güvenlik kavramlarının bulunması, bu konudaki literatürü destekler niteliktedir.

Araştırma bulgularına göre, kızların problem durumu karşısında daha yapıcı/işlevsel çözümler sundukları, erkeklerin ise problem durumlarından kaçınmaya eğilimli oldukları ya da problemi görmezden gelmeyi tercih ettikleri görülmüştür (Bkz. Tablo2, 3 ve 5). Literatür incelendiğinde kızlar ile erkeklerin problem çözme beceri puanları arasında anlamlı bir farklılık olmadığını söyleyen araştırmalar olduğu gibi (Dereli-İman, 2013; Terzi 2003; Yılmaz \& Tepeli, 2013), cinsiyetin problem çözme becerilerini etkilediğini söyleyen araştırma bulguları da mevcuttur (Bukowski, 1990; Musun-Miller, 1993; Walker vd., 2002). Cinsiyetin etkisinden söz eden bu araştırmalar, sosyal problemleri çözmede kızların erkeklerden daha iyi olduğunu belirtmektedir. Bu bulgular araştırmamızın bulgularıyla paralellik göstermektedir. Çalışma grubunda erkeklerin problemlerin çözümü karşısında aktif bir rol almamayı tercih ettikleri görülmektedir. Oysa buna karşın kızlar problem durumu karşısında sorumluluk almış ve çözüm sürecine katkı sunmaya çalışmışlardır. Bu grupta erkeklerin problem durumlarından kaçınmaya eğilimli olmaları, algıladıkları cinsiyet rolleriyle ilişkili olabilir. Kültürümüzde, kızlara daha korumacı davranılmakta, daha çok baskı uygulanmakta ve çoğu zaman erkeklerin hak ve ayrıcalıklarından yoksun bırakılmaktadırlar. Bu durum kızların karşılaştıkları sorunları daha çok önemsemesine ve bu sorunları çözmek için harekete geçmesine neden olmuştur. Bu durumun erkeklerin yetişkinlerden gördükleri ayrıcalıklı tutum neticesinde sorunlar karşısında umursamaz davranmasına yol açtığı düşünülebilir.

Araştırmanın bir diğer önemli bulgusu ise, çocukların problem durumları karşısında hissedilen olumsuz duyguları kontrol altına alabilmeleridir. Örneğin çocuklar kızgınlık (Bkz. Tablo3) ve hayal kırıklığı duygularını (Bkz. Tablo5) kontrol edebilmiş, hazzı erteleyebilmiş, duygu ve isteklerini kontrol altına alabilmişlerdir (Bkz. Tablo6). Bu bulgular çocukların öz düzenleme yapabildiklerinin bir göstergesidir ve öz düzenleme becerilerinin okul öncesi dönemde, özellikle beş yaşta önemli ilerlemeler kaydettiğini söyleyen literatür bilgileri ile uyumludur (Kochanska, Coy, ve Murray, 2001; Zelazo, Carlson ve Kesek, 2008).

İkinci problem durumuna verilen çözüm önerilerinde çocuklardan hiçbirinin kardeşine yönelik olumsuz ve saldırgan tutum içeren davranışta bulunacağını belirtmediği ve üçüncü problem durumuna verilen çözüm 
önerilerine bakıldığında ise özellikle üç çocuğun $(K 4, K 5, E 3)$ havanın soğuk olmasından dolayı annelerinin, kendilerinin üşüyeceklerini varsayarak belirtilen tişörtü giymesine izin vermediğini düşündükleri göze çarpmaktadır. Bu bulgular araştırmaya katılan çocukların karşılarındaki insanların istek, niyet, duygularını anlama ve insanlarla olan iletişiminde bu zihinsel durumlara göre açıklama ve yorumlama getirebilme becerisi olarak tanımlanan zihin kuramı becerilerine sahip bireyler olduklarını göstermektedir (Astington ve Baird, 2005). Bu durum beş yaş civarında çocukların zihin teorisi becerilerini etkili bir şekilde kullanabildiğini söyleyen Carlson ve Moses'ın (2001) çalışmalarıyla paralellik göstermektedir.

Okul öncesi dönemde çocukların problem durumları karşısında duygularını nasıl ifade ettikleri, problemlere nasıl çözümler ürettikleri ve bu çözümlerin cinsiyete göre farklılaşıp farklılaşmadığının incelendiği bu araştırmada, araştırmaya katılan beş yaş çocuklarının problem çözme süreçlerinde etkili olan ve zihin kuramı becerileriyle de doğrudan ilişki içerisinde bulunan empati ve öz düzenleme becerilerinde başarılı oldukları görülmüştür. Çocuklar problem durumlarındaki karakter ile empati kurabilmiş ve olaylara onun açısından bakabilmiştir, ancak karakterin hissettiği duyguları doğru olarak isimlendirmede zorlanmışlardır. Ayrıca kızların erkeklere göre problem durumları karşısında daha yapıcı/işlevsel çözümler sundukları, erkeklerin ise problemlerden kaçınmaya eğilimli oldukları ya da görmezden geldikleri görülmüştür. Bu bulgular, çocukların gelişimlerinde ve beceri kazanma süreçlerinde cinsiyetin dezavantaj yaratan bir faktör haline gelmemesi için, çocuklara cinsiyet rolleri yüklerken,hem ailelerin hem de eğitimcilerin daha objektif davranmaya özen göstermeleri gerektiğinin bir göstergesidir. Aynı zamanda başta ebeveynler olmak üzere, eğitimcilerin de duygular üzerinde durması ve çocukları duyguları üzerinde düşünmeye teşvik etmesi önemlidir.

\section{ÖNERILER}

Nitel araştırmaların doğası gereği, bu araştırmanın bulguları özneldir ve genelleme yapmaya uygun değildir (Yıldırım ve Şimşek, 2016). Ancak bu bulgular ile okuyucular ve diğer araştırmacılar için, beş yaş çocuklarının duygularını ifade ediş biçimlerine ve problem durumlarına ürettikleri çözümlere örnekler ortaya koyabilmek, zihin kuramı, empati ve öz düzenleme becerilerine ilişkin anlayış ile deneyimlerin gelişmesine katkıda bulunabilmek hedeflenmektedir. Bu bulgular göz önüne alınarak, daha büyük örneklem grupları ile zihin kuramı, problem çözme, empati ve öz düzenleme becerileri ile ilgili yapılacak nitel çalışmaların, bu becerilerin gelişim süreçlerinin daha iyi anlaşılmasına yardımcı olacağı düşünülmektedir.

\section{ETIK METNi}

Bu makalede dergi yazım kurallarına, yayın ilkelerine, araştırma ve yayın etiği kurallarına, dergi etik kurallarına uyulmuştur. Makale ile ilgili doğabilecek her türlü ihlallerde sorumluluk yazar(lar)a aittir. 


\section{KAYNAKÇA}

Astington, J. W. ve Baird, J. A. (Eds.). (2005). Why language matters for theory of mind. Oxford University Press. Astington, J.W. ve Gopnik, A. (1991). Theoretical explanations of children's understanding of the mind. British Journal of Developmental Psychology, 9, 7-31.

Baran, G. ve Erdoğan, S. (2007). A research on perspective taking skills and the social behaviour of six-year-old girls and boys. Pakistan Journal of Social Sciences, 4(2): 236-239.

Bauer, I. M. ve Baumeister, R. F. (2011). Self-regulatory strenght. In K. D. Vohs, R. F. Baumeister (Eds.), Handbook of Self-Regulation: Research, Theory, and Applications. New York: Guilford Press.

Bierman, K. L., Nix, R. L., Greenberg, M. T., Blair, C. ve Domitrovich, C. E. (2008). Executive functions and school readiness intervention: Impact, moderation, and mediation in the Head Start REDI program. Development and Psychopathology, 20, 821-843.

Bondurant, L. M. (2010). The roots of academic underachievement: Prediction from early difficulties with selfregulation. (PhD thesis, The University of Texas), Proquest Information and Learning Company. (UMI 3421467).

Bukowski, W. M. (1990). Age differences in children's memory of information about guests and hosts to peer group entry. Child Development, 62: 1079-1090.

Carlson, S. M. ve Moses, L.J. (2001). Individual differences in inhibitory control and children's theory of mind. Child Development, 72: 1032-1053.

Cole, P. M., Zahn-Waxler, C., Fox, N. A., Usher, B. A. ve Welsh, J. D. (1996). Individual differences in emotion regulation and behavior problems in preschool children. Journal of Abnormal Psychology, 105(4), 518529.

D’zurilla, T.J., Nezu, A.M. ve Maydeu-Olivares, A. (2004). Social Problem Solving: Theory and Assessment. In E. C. Chang, T. J. D’Zurilla, L. J. Sanna (Eds.), Social problem solving: Theory, research, and training. Retrieved from http://www.ub.edu/gdne/documents/sps chapter_in_APA_book.pdf

Dereli-İman, E. (2013). Cocuklar icin sosyal problem çözme olcegi'nin 6 yaş grubu icin Turkiye uyarlamasi ve okul öncesi davranis problemleri ile sosyal problem cozme becerileri arasindaki iliskiler [Adaptation of social problem solving for children questionnaire in 6 age groups and its relationship with preschool behavior problems]. Kuram ve Uygulamada Egitim Bilimleri, 13(1): 479-498.

Downs, A. ve Strand, P. (2008). Effectiveness of emotion recognition training for young children with developmental delays. Journal of Early and Intensive Behavior Intervention, 5(1): 75-89.

Eskin, M. (2009). Sorun cozme terapisi [Problem solving therapy]. Ankara: HYB Basim Yayin.

Fabes, R. A. ve Eisenberg, N. (1992). Young children's coping with interpersonal anger. Child Development, 63, 116-128.

Fabes, R. A., Eisenberg, N., Jones, S., Smith, M., Guthrie, I., Poulin, R., ... ve Friedman, J. (1999). Regulation, emotionality, and preschoolers' socially competent peer interactions. Child Development, 70(2), 432442. 
Garner, P W. ve Waajid, B. (2012). Emotion knowledge and self-regulation as predictors of preschoolers' cognitive ability, classroom behavior, and social competence. Journal of Psycheducational Assessment, 30(4): 330-343.

Greenspan, S. I. ve Salmon, J. (2013). Meydan okuyan cocuk: Bes tip "guç" cocugu anlama, yetistirme ve onlardan hoslanma [The challenging child: Understanding, raising, and enjoying the five" difficult" types of children]. (Cev. I. Ersevim). İstanbul: Ozgur Yayinlari.

Greenspan, S. I., Wieder, S. ve Simons, R. (2016). Ozel gereksinimli cocuk: Zihinsel ve duygusal gelisim [The child with special needs: Encouraging intellectual and emotional growth]. Cev., I. Ersevim. İstanbul: Ozgur Yayinlari.

Heppner, P.P. ve Krauskopf, C.J. (1987). An information-processing approach to personal problem solving. Counseling Psychologist, 15: 371-447.

Hill, A. L., Degnan, K. A., Calkins, S. D. ve Keane, S. P. (2006). Profiles of externalizing behavior problems for boys and girls across preschool: The roles of emotion regulation and inattention. Developmental Psychology, 42(5), 913-928.

Kochanska, G., Coy, K. C. ve Murray, K. T. (2001). The development of self-regulation in the first four years of life. Child Development, 72: 1091-1111.

Kocak, R. (2002). Aleksitimi: Kuramsal cerceve tedavi yaklasimlari ve ilgili arastirmalar [Alexithymia: Theoretical framework treatment approaches and related researches]. Ankara Universitesi Egitim Bilimleri Fakültesi Dergisi, 35(1-2): 183-212.

Koole, S. L., Van Dillen, L. F. ve Sheppes, G. (2011). The self-regulation of emotion. In K. D. Vohs, R. F. Baumeister (Eds.), Handbook of Self-Regulation: Research, Theory, and Applications. New York: Guilford Press.

Koksal Akyol, A. ve Didin, E. (2016). Ahlak gelisimi [Moral development]. Cocuk Gelisimi icinde [In Child Development], N. Aral (Ed.). Anadolu Universitesi Yayinlari.

Ljungberg, T., Horowitz, L., Jansson, L., Westlund, K. ve Clarke, C. (2005). Communicative factors, conflict progression, and use of reconciliatory strategies in pre-school boys-a series of random events or a sequential process?. Aggressive Behavior, 31(4): 303-323.

Marvin, R.S., Greenberg, M.T. ve Mossler, D.G. (1976). The early development of conceptual perspective taking: Distinguishing among multiple perspectives. Child Development, 47: 511-514.

McClelland, M. M. ve Tominey, S. L. (2011). Introduction to the special issue on self-regulation in early childhood. Early Education \& Development, 22(3), 355-359.

Merriam, S. B. (2015). Nitel arastirma [Qualitative research]. Cev. Ed,. Selahattin Turan). Ankara: Nobel.

Miles, M. B. ve Huberman, A. M. (2015). Nitel veri analizi [Qualitative data analysis] Cev. Ed., S. Akbaba Altun, A. Ersoy. Ankara: Pegem.

Montroy, J. J., Bowles, R. P., Skibbe, L. E. ve Foster, T. D. (2014). Social skills and problem behaviors as mediators of the relationship between behavioral self-regulation and academic achievement. Early Childhood Research Quarterly, 29(3), 298-309. 
Musun-Miller, L. (1993). Social acceptance and social problem solving in preschool children. Journal of Applied Developmental Psychology, 14, 59-70.

Nota, L., Soresi, S. ve Zimmerman, B. J. (2004). Self-regulation and academic achievement and resilience: A longitudinal study. International Journal of Educational Research, 41(3), 198-215.

Onishi, K. H. ve Baillergeon, R. (2005). Do 15-month-old infants understand false belief?. Science, 308: 255-258.

Raffaelli, M., Crockett, L. J. ve Shen, Y. L. (2005). Developmental stability and change in self-regulation from childhood to adolescence. The Journal of Genetic Psychology, 166(1), 54-76.

Raver, C. C., Li-Grining, C., Bub , K., Jones, S. M., Zhai, F. ve Pressler, E. (2011). CSRP's impact on low-income preschoolers' preacademic skills: self-regulation as a mediating mechanism. Child Development, 82(1), 362-378.

Riggs, N.R., Jahromi, L.B., Razza, R.P., Dillworth-Bart, J.E. ve Mueller, U. (2006). Executive function and the promotion of social-emotional competence. Journal of Applied Developmental Psychology, 27: 300309.

Senemoglu, N. (2007). Gelisim, ögrenme ve ögretim: Kuramdan uygulamaya [Development, learning and teaching: From theory to practice]. Ankara: Gonul Yayincilik.

Smith-Donald, R., Raver, C.C., Hayes, T. ve Richardson, B. (2007). Preliminary construct and concurrent validity of the Preschool Self-regulation Assessment (PSRA) for field-based research. Early Childhood Research Quarterly, 22, 173-187.

Sodian, B. (2011). Theory of mind in infancy. Child Development Perspectives, 5: 39-43.

Southam-Gerow, M.A. (2014). Cocuklarda ve ergenlerde duygusal düzenleme [Emotional regulation in children and adolescents] Cev. Ed., M. Sahin., Cev., M. Artiran. Ankara: Nobel.

Taylor, G. J. (2001). Recent developments in alexithymia theory and research. Can J Psychiatry, 45:134-142.

Terzi, S. (2003). Altıncı sinif ögrencilerinin kisiler arası problem cözme beceri algilari [Interpersonal problem solving skills perceptions of sixth grade students]. Turk Egitim Bilimleri Dergisi, 1(2).

Tulviste, T. ve Koor, M. (2005). “Hands off the car, it's mine!” and "The teacher will be angry if we don't play nicely": Gender-related preferences in the use of moral rules and social conventions in preschoolers' dyadic play. Sex Roles, 53(1): 57-66.

Walker, S., Irving, K. ve Berthelsen, D. (2002). Gender influences on preschool children's social problem-solving strategies. The Journal of Genetic Psychology, 163(2): 197-209.

Wellman, H. (1990). The child's theory of mind. Cambridge, MA: MIT Press

Wellman, H. ve Lagattuta, K.H. (2000). Developing understandings of mind. In S. Baron-Cohen, H. TagerFlusberg, D.J. Cohen (Eds.), Understanding other minds: Perspectives from developmental cognitive neuroscience. Oxford: Oxford University Press.

Westlund, K., Horowitz, L., Jansson, L. ve Ljungberg, T. (2008). Age effects and gender differences on postconflict reconciliation in preschool children. Behaviour, 145(11): 1525-1556.

Yildirim, A. ve Simsek, H. (2016). Sosyal bilimlerde nitel arastirma yontemleri [Qualitative research methods in the social sciences]. Ankara: Seckin. 
Yilmaz, E. ve Tepeli, K. (2013). 60-72 Aylik cocuklarin sosyal problem cözme becerilerinin duyguları anlama becerileri acisindan incelenmesi [Examinatıon of social problem solving skills of 60-72 months old children in terms of their emotion understanding skilla]. Turkiye Sosyal Arastirmalar Dergisi, 172(172): 117-130.

Zelazo, P. D., Carlson, S. M. ve Kesek, A. (2008). The development of executive function in childhood. In C. Nelson \& M. Luciana (Ed.), Handbook of developmental cognitive neuroscience (2nd ed., pp. 553-574). Cambridge, MA: MIT Press.

Zimmerman, B. J. (2000). Attaining self-regulation: A social cognitive perspective. In M. Boekaerts, P. R., Pintrich, M. Zeidner (Eds.), Handbook of selfregulation. San Diego, CA: Academic Press. 